\title{
Marine biogeochemical responses to the North Atlantic Oscillation in a coupled climate model
}

\author{
Lavinia Patara, ${ }^{1,2}$ Martin Visbeck, ${ }^{3}$ Simona Masina, ${ }^{1,4}$ Gerd Krahmann, ${ }^{3}$ \\ and Marcello Vichi ${ }^{1,4}$ \\ Received 3 November 2010; revised 12 April 2011; accepted 2 May 2011; published 27 July 2011.
}

[1] In this study a coupled ocean-atmosphere model containing interactive marine biogeochemistry is used to analyze interannual, lagged, and decadal marine biogeochemical responses to the North Atlantic Oscillation (NAO), the dominant mode of North Atlantic atmospheric variability. The coupled model adequately reproduces present-day climatologies and NAO atmospheric variability. It is shown that marine biogeochemical responses to the NAO are governed by different mechanisms according to the time scale considered. On interannual time scales, local changes in vertical mixing, caused by modifications in air-sea heat, freshwater, and momentum fluxes, are most relevant in influencing phytoplankton growth through light and nutrient limitation mechanisms. At subpolar latitudes, deeper mixing occurring during positive NAO winters causes a slight decrease in late winter chlorophyll concentration due to light limitation and a $10 \%-20 \%$ increase in spring chlorophyll concentration due to higher nutrient availability. The lagged response of physical and biogeochemical properties to a high NAO winter shows some memory in the following 2 years. In particular, subsurface nutrient anomalies generated by local changes in mixing near the American coast are advected along the North Atlantic Current, where they are suggested to affect downstream chlorophyll concentration with 1 year lag. On decadal time scales, local and remote mechanisms act contemporaneously in shaping the decadal biogeochemical response to the NAO. The slow circulation adjustment, in response to NAO wind stress curl anomalies, causes a basin redistribution of heat, freshwater, and biogeochemical properties which, in turn, modifies the spatial structure of the subpolar chlorophyll bloom.

Citation: Patara, L., M. Visbeck, S. Masina, G. Krahmann, and M. Vichi (2011), Marine biogeochemical responses to the North Atlantic Oscillation in a coupled climate model, J. Geophys. Res., 116, C07023, doi:10.1029/2010JC006785.

\section{Introduction}

[2] Assessing the mechanisms of marine biogeochemical natural variability from interannual to decadal time scales is crucial for better understanding the functioning of the Earth System. In fact biogeochemical processes are at the base of ocean ecosystems, affect the $\mathrm{CO}_{2}$ redistribution between oceanic and atmospheric compartments, and are ultimately capable of generating feedbacks onto physical climate properties [Denman et al., 2007]. Marine biogeochemical processes naturally exhibit interannual-to-decadal fluctuations in response to large-scale patterns of internal climate variability [Gruber et al., 2002; Drinkwater et al., 2003; Watson et al., 2009], and there is a clear need to distinguish natural

\footnotetext{
Centro Euro-Mediterraneo per i Cambiamenti Climatici, Bologna, Italy.

${ }^{2}$ Now at Leibniz Institute of Marine Sciences at University of Kiel (IFM-GEOMAR), Kiel, Germany.

${ }^{3}$ Leibniz Institute of Marine Sciences at University of Kiel (IFMGEOMAR), Kiel, Germany.

${ }^{4}$ Istituto Nazionale di Geofisica e Vulcanologia, Bologna, Italy.

Copyright 2011 by the American Geophysical Union. 0148-0227/11/2010JC006785
}

variability from external sources of climate variation such as the anthropogenic one. A key region in this respect is the North Atlantic Ocean, which exhibits among the most extensive phytoplankton blooms globally [McClain, 2009] and which is currently one of the largest oceanic sinks of atmospheric $\mathrm{CO}_{2}$ [Sabine et al., 2004]. The primary mode of climate variability in the North Atlantic sector from interannual to decadal time scales is the North Atlantic Oscillation [Walker and Bliss, 1932; Bjerknes, 1964; Hurrell, 1995] which involves a redistribution of atmospheric mass between subtropical and arctic latitudes and as such determines the position and strength of westerly storm tracks crossing the North Atlantic basin [Hurrell et al., 2003].

[3] Numerous studies have investigated how wind changes associated with the North Atlantic Oscillation (NAO) may affect ocean physical properties on interannual and decadal time scales. On interannual time scales the ocean response to the NAO is suggested to be mainly dictated by modifications in air-sea fluxes of heat, freshwater, and momentum [Cayan, 1992; Marshall et al., 2001]. In fact stronger and northerly displaced westerly winds, occurring during positive index phases (hereafter $\mathrm{NAO}+$ ), lead to changes in latent and sensible heat fluxes which produce a tripolar structure of 
decreased sea surface temperature (SST) at subpolar and tropical latitudes and increased SST at middle-subtropical latitudes [Cayan, 1992; Visbeck et al., 2003]. Momentum flux changes cause an instantaneous wind-driven response of surface currents which are also suggested to have a relevant role in determining the temperature and salinity response to interannual NAO fluctuations [Mignot and Frankignoul, 2004].

[4] Several studies have shown that the ocean response to the NAO does not exhaust itself within the year in which the forcing takes place, but persists also in following years [e.g., Visbeck et al., 2003]. This is attained through several mechanisms: for instance, Sutton and Allen [1997] find SST persistence and propagation along the North Atlantic Current in winters following a high NAO index, and invoke the combined action of advection by mean current systems and the winter "reemergence" of subsurface temperature anomalies shielded by shallow summer mixed layers [Alexander and Deser, 1995]. Other studies have also shown that ocean circulation itself exhibits a slow adjustment to wind stress curl anomalies induced by the NAO. Indeed, the baroclinic response of the Gulf Stream-North Atlantic Current system [Curry and McCartney, 2001; Frankignoul et al., 2001; Flatau et al., 2003] and of the subpolar gyre strength [Bersch, 2002; Haekkinen and Rhines, 2004; Böning et al., 2006; Lohmann et al., 2009] were found to be maximum with a few years lag with respect to a high NAO index winter. It is suggested that low-frequency changes in ocean circulation in response to the persistent action of NAO wind stress curl forcing may actively generate temperature and salinity anomalies on decadal time scales [Visbeck et al., 2003]. For instance, the "spin-up" of the subpolar gyre circulation occurring in decades of predominantly NAO+ forcing was invoked as a possible mechanism for the concurrent subpolar freshening and cooling [Bersch, 2002; Flatau et al., 2003; Belkin, 2004]. Changes in the Atlantic meridional overturning circulation are also expected to modify the heat and freshwater transport to subpolar latitudes [Eden and Jung, 2001; Frankignoul et al., 2009]. Because of the slow adjustment of the North Atlantic Ocean circulation and of its capability of integrating atmospheric forcing in time, significant ocean memory to previous NAO decadal phases persists also when the forcing ceases, i.e., in quadrature with the NAO forcing [Visbeck et al., 1998; Krahmann et al., 2001]. These past results thus suggest the ocean response on interannual and decadal time scales may significantly differ because of the varying importance of air-sea versus advective fluxes.

[5] Understanding the mechanisms and the specific properties of the interannual and decadal ocean physical responses to the NAO is a critical step for comprehending and possibly predicting marine biogeochemical responses to the NAO as well. Previous studies have shown that ocean temperature and mixing changes associated with high NAO index winters are capable of affecting the phytoplankton bloom properties. At subpolar latitudes, satellite and modeling data have shown that during $\mathrm{NAO}+$ years deeper-than-average winter mixing causes a shortening of the phytoplankton growing season associated with a reduction of the average spring bloom magnitude [Barton et al., 2003; Henson et al., 2006, 2009]. This behavior is consistent with Sverdrup [1953] critical layer hypothesis, affirming that when mixing exceeds a certain critical depth phytoplankton cells will be limited in their growth by sunlight availability. In a 50 year time series from the Continuous Plankton Recorder, Barton et al. [2003] detected a positive correlation between $\mathrm{NAO}+$ and chlorophyll in the subpolar-subtropical transition zone possibly due to higher nutrient availability, and a negative correlation at high latitudes possibly due to light limitation. However, these authors also found that correlations are not significant when the time series are detrended, which would suggest a stronger influence of NAO on decadal, rather than interannual, time scales. In addition, in a few year time series of chlorophyll satellite measurements, Follows and Dutkiewicz [2002] found that at subpolar latitudes spatial chlorophyll variability dominates over interannual variability, possibly because of the strong mesoscale field, the shortness of the available time series, and the elevated cloudiness which reduces satellite coverage. At subtropical latitudes deeper mixing is found to increase phytoplankton growth through increased nutrient availability [Follows and Dutkiewicz, 2002], even though ocean advective processes are also suggested to be relevant in determining the nutrient response to the NAO [Oschlies, 2001]. Furthermore, interannual variability of subsurface nutrient reservoirs was found to affect downstream primary productivity within the North Atlantic Subtropical Mode Waters [Palter et al., 2005].

[6] The variability of the North Atlantic Ocean $\mathrm{CO}_{2}$ uptake in response to the NAO was found in previous studies to be governed by a multitude of thermodynamic and biological processes, capable of modifying the air-sea difference in $\mathrm{CO}_{2}$ partial pressure and the $\mathrm{CO}_{2}$ flux magnitude [Gruber et al., 2002; Bates, 2007; Corbière et al., 2007; Thomas et al., 2008; Watson et al., 2009]. The estimated interannual variability of the North Atlantic Ocean $\mathrm{CO}_{2}$ uptake ranges between less than 0.1 and more than $0.3 \mathrm{PgC} \mathrm{yr}^{-1}$ [Le Quéré et al., 2000; Gruber et al., 2002; Schuster and Watson, 2007], even though other authors also found that $\mathrm{CO}_{2}$ uptake variability may be higher on decadal rather than on interannual time scales [Raynaud et al., 2006; Löptien and Eden, 2010].

[7] These past studies delineate a complex picture in which marine biogeochemistry may respond to NAO variability on various time scales (e.g., interannual, decadal) and through different mechanisms (e.g., mixing, advection). Because of the shortness and low spatial coverage of currently available observations, insights on longer-term and basin-scale system behavior can only be obtained through ocean models. In particular coupled ocean-atmosphere models, capable of internally generating NAO-like variability and of being integrated for several centuries, have recently been used to skillfully investigate NAO-ocean coupling on decadal time scales or longer [e.g., Delworth and Mann, 2000; Bellucci et al., 2008; Frankignoul et al., 2009]. This paper aims at making a step forward in this research by exploiting the potential of a coupled climate model including interactive marine biogeochemistry to investigate natural biogeochemical variability in the North Atlantic Ocean. A 300 year present climate simulation is performed and analyzed to elucidate interannual, lagged, and decadal biogeochemical responses to the NAO, and to identify the associated physical forcing mechanisms within a fully coupled and dynamically consistent climate framework.

[8] This paper is structured as follows: section 2 describes the coupled model employed in this study and its performance in the North Atlantic in terms of climatology and atmospheric 
variability. Section 3 investigates the direct response of marine biogeochemistry to high NAO index winters (interannual response), whereas section 4 examines how high NAO index winters may influence marine biogeochemistry in subsequent years (lagged response). Section 5 analyzes marine biogeochemical responses to low-frequency NAO forcing during decades in which the NAO persists in mostly one phase (decadal response). Section 6 discusses and summarizes the main results of this study.

\section{Methods}

\subsection{Coupled Model Description and Experiment Setup}

[9] The coupled ocean-atmosphere general circulation model used in this study combines the ocean model OPA 8.1 [Madec et al., 1998] with the atmospheric model ECHAM5 [Röckner et al., 2003] by means of the OASIS3 coupler [Valcke et al., 2004]. The ocean model includes the sea ice model LIM2 [Timmermann et al., 2005] and the marine biogeochemistry model PELAGOS [Vichi et al., 2007a]. A brief description of the model components will be here given, whereas a more complete technical description is given by Fogli et al. [2009].

[10] The atmosphere general circulation model ECHAM5 is used with a T31 horizontal resolution $\left(3.75^{\circ}\right.$ horizontal grid spacing) and 19 vertical levels. The ocean general circulation model OPA 8.1 is implemented on the global curvilinear and tripolar ORCA2 grid [Madec and Imbard, 1996] characterized by a horizontal resolution of $2^{\circ} \times 2^{\circ} \cos \theta$ in the region of interest and 31 unevenly spaced vertical levels $(10 \mathrm{~m}$ thickness in the upper $100 \mathrm{~m}$ ). Employed parameterizations and settings used for OPA 8.1 are described by Vichi et al. [2007b]. The ocean and the atmosphere exchange momentum, heat, and freshwater once a day by means of the OASIS3 coupler which ensures heat and freshwater conservation without any flux correction.

[11] The marine biogeochemistry model PELAGOS [Vichi et al., 2007a] is the global implementation of the Biogeochemical Flux Model (BFM, http://bfm.cmcc.it) and has shown skill at reproducing observed climatologies and interannual variability of biogeochemical properties [Vichi and Masina, 2009; Vichi et al., 2007b]. It includes a comprehensive set of marine biogeochemical relations for major inorganic compounds (nitrate, ammonia, phosphate, silicate, iron, dissolved inorganic carbon, oxygen), organic compounds (dissolved and particulate organic matter), and lower trophic levels of the marine ecosystem. Three phytoplankton groups (diatoms, nanophytoplankton and picophytoplankton), three zooplankton groups (nanozooplankton, microzooplankton, and mesozooplankton), and one bacterioplankton group are described according to their physiological requirements and feeding interactions. Nutrient uptake is parameterized following a Droop kinetics [Vichi et al., 2007a] which allows for multinutrient limitation and variable internally regulated nutrient ratios. Chlorophyll synthesis is down regulated when the rate of light absorption exceeds the utilization of photons for carbon fixation [Geider et al., 1997]. Dissolved inorganic iron is explicitly simulated and treated as an internal constituent of phytoplankton [ Vichi et al., 2007a]. PELAGOS describes the carbonate system in seawater in terms of 7 chemical species, i.e., total carbon concentration, total alkalinity, free carbon dioxide, bicar- bonate ion, carbonate ion, carbon dioxide partial pressure in seawater (hereafter $\mathrm{pCO}_{2}$ ), and $\mathrm{pH}$ [Zeebe and WolfGladrow, 2001]. Alkalinity does not vary actively as a function of calcium carbonate and riverine inputs but only passively as a function of advective and diffusive physical processes. The local equilibrium carbonate chemistry is solved according to the simplified method proposed by Follows et al. [2006] for the computation of hydrogen ion concentration. Surface $\mathrm{pCO}_{2}$ is computed as a function of free carbon dioxide and of the Henry's constant regulating the temperature-dependent $\mathrm{CO}_{2}$ solubility in seawater. The air-sea difference in $\mathrm{pCO}_{2}$ drives a $\mathrm{CO}_{2}$ flux between the two compartments as a function of Henry's constant and the gas transfer coefficient [Wanninkhof, 1992].

[12] The coupled model is used to produce a 300 year simulation starting from a physics-only 100 year simulation, in turn initialized using World Ocean Atlas 1998 climatologies for ocean temperature and salinity [Levitus et al., 1998]. Marine biogeochemistry is initialized using World Ocean Atlas 2001 climatologies for macronutrients, dissolved inorganic carbon, and alkalinity [Conkright et al., 2002; Key et al., 2004] and by prescribing uniform concentrations for the remaining variables. Atmospheric $\mathrm{CO}_{2}$ concentration is set to a constant value of $348 \mathrm{ppm}$ used for both atmospheric radiation and air-sea $\mathrm{CO}_{2}$ flux computations, and ozone is prescribed according to the Fortuin and Kelder [1998] climatology. During the model integration atmospheric iron deposition is taken into account by using climatological model data from Tegen and Fung [1994] assuming a constant dissolution fraction of $1 \%$.

\subsection{Model Performance in the North Atlantic}

[13] Figure 1 shows the climatological state simulated by the coupled model and some of its biases with respect to observational reanalyses. Simulated December-March (hereafter DJFM) wind stress (Figure 1a) has a westward component between $35^{\circ} \mathrm{N}$ and $55^{\circ} \mathrm{N}$ and tends to be overestimated in the eastern part of the basin with respect to the ERA-40 reanalyses [Uppala et al., 2005]. Compared with the Hadley SST observational data set [Rayner et al., 2003], DJFM sea surface temperature (hereafter SST) is underestimated in the central subpolar gyre and overestimated along the North American coast (Figure 1b, colors). These SST biases are known to affect, with similar magnitudes, most climate models used for the IPCC Fourth Assessment Report [Randall et al., 2007, Figure 8.2] and are thought to be related with displacements of ocean currents (Figure $1 \mathrm{~b}$, arrows). Indeed, when visually comparing the simulated surface circulation with observational data sets [e.g., Reverdin et al., 2003], it can be seen that the Gulf Stream detaches a few degrees northward than observed thereby causing the warm SST bias along the North American Coast, and the Labrador Current is overly strong thereby producing the cold SST bias in the western subpolar gyre. Displacements of the simulated horizontal circulation, possibly caused by the low resolution of the employed bathymetry and of the atmospheric forcing, cause biases also in sea surface salinity (hereafter SSS), i.e., a negative bias in the subpolar gyre and a positive bias along the North American coast (not shown).

[14] Mixed layer depth (hereafter MLD) in the model is computed as the depth where the density increase compared to surface density equals $0.01 \mathrm{~kg} \mathrm{~m}^{-3}$. Winter MLD maxima 

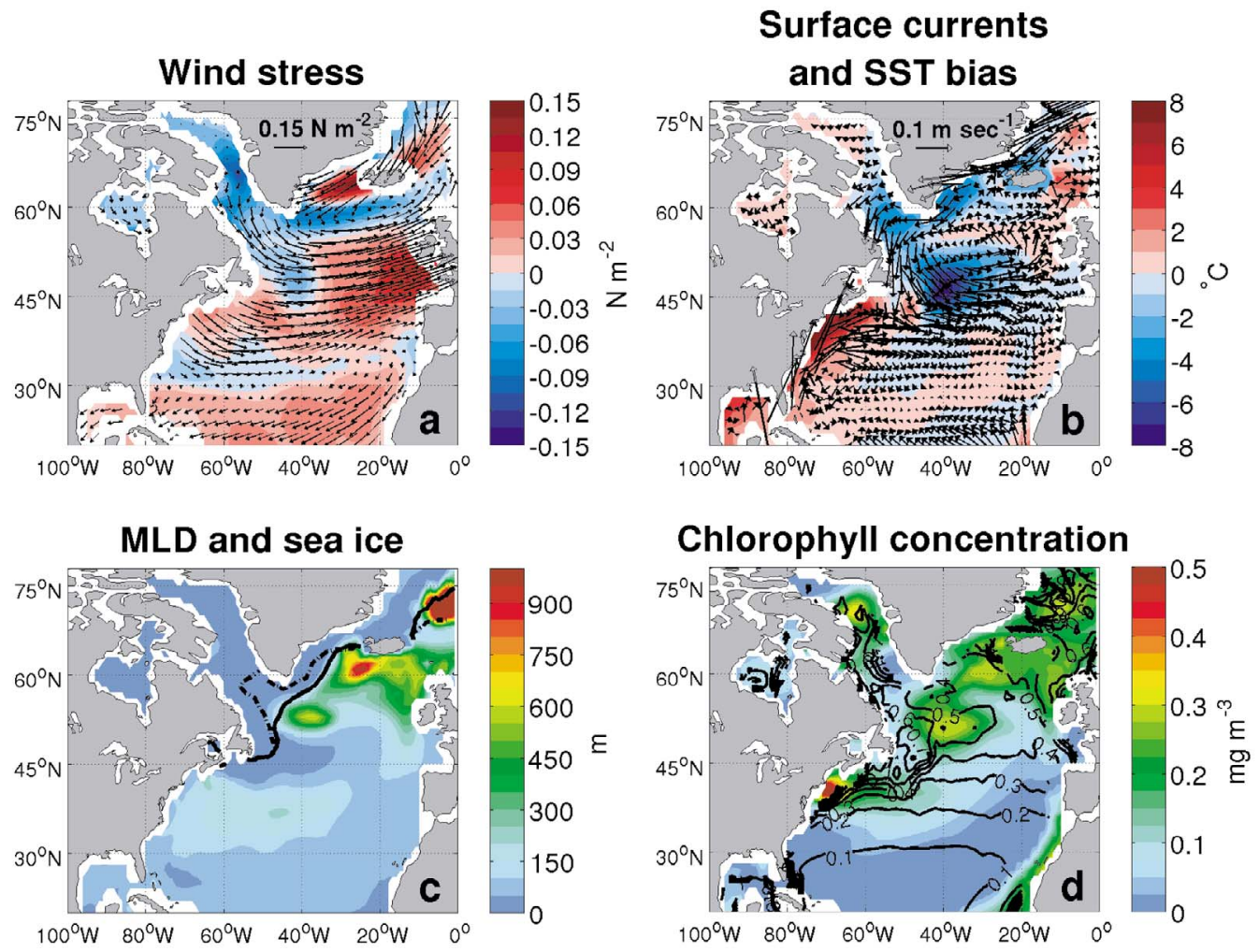

Figure 1. Model climatologies and biases: (a) simulated December-March (DJFM) wind stress in $\mathrm{N} \mathrm{m}^{-2}$ (arrows) and its bias in magnitude with respect to ERA-40 reanalysis (colors), (b) simulated DJFM sea surface temperature (SST) bias in ${ }^{\circ} \mathrm{C}$ with respect to Hadley SST (colors) and simulated DJFM ocean surface currents in $\mathrm{m} \mathrm{s}^{-1}$ (arrows), (c) simulated DJFM mixed layer depth (MLD) in $\mathrm{m}$ (colors) and sea ice edge (1\% sea ice cover) in the model (solid line) and in the Hadley data set for the years 1960-1999 (dashed line), and (d) simulated annual chlorophyll concentration averaged over the euphotic layer in $\mathrm{mg} \mathrm{m}^{-3}$ (colors) and SeaWiFS satellite chlorophyll estimates in $\mathrm{mg} \mathrm{m}^{-3}$ (contours).

in the model are found in the Irminger Sea and in the Nordic Seas (Figure 1c, colors) but not in the Labrador Sea, as instead seen in observational estimates from de Boyer Montégut et al. [2004]. This is due to overestimated sea ice cover in the model (Figure 1c, thick line) compared to the Hadley observational data set [Rayner et al., 2003] for the years 1960-1999 (Figure 1c, dashed line). Ocean winter mixing is relevant for phytoplankton growth as it delivers nutrients to the euphotic layer. The annual chlorophyll concentration averaged over the euphotic layer depth (Figure 1d, colors) is in fact higher in areas of deeper mixing, namely at subpolar and western middle latitudes, and lower in the subtropical gyre. Compared with SeaWiFS satellite chlorophyll estimates [McClain, 2009] for the years 1998-2006 (Figure 1d, contours), it can be seen that the main features of the chlorophyll field are correctly simulated even though values tend to be overall underestimated. This is related to a long-term chlorophyll decrease in the North Atlantic (Figure 2c), possibly caused by an unbalance between export of organic matter (and nutrients) into deep ocean layers and nutrient resupply into the euphotic layer.

[15] SST and SSS averaged over the North Atlantic basin $\left[20^{\circ} \mathrm{N}-70^{\circ} \mathrm{N}, 90^{\circ} \mathrm{W}-40^{\circ} \mathrm{E}\right]$ are in near equilibrium during the last 200 years of the model simulation (Figures $2 \mathrm{a}$ and $2 \mathrm{~b}$ ). Chlorophyll concentration exhibits instead a large adjustment trend which tends to stabilize during the last 100 years of simulation (Figure 2c). Physical monthly outputs are thus analyzed over the last 200 years of simulation, whereas biogeochemical monthly outputs are analyzed over the last 100 years after having detrended them with a second-order polynomial fit (Figure 2d).

\subsection{North Atlantic Atmospheric Variability}

[16] North Atlantic atmospheric variability is analyzed by means of Principal Component Analysis applied on DJFM sea level pressure (hereafter SLP) anomalies in the North Atlantic sector $\left[20^{\circ} \mathrm{N}-70^{\circ} \mathrm{N}, 90^{\circ} \mathrm{W}-40^{\circ} \mathrm{E}\right]$. The $\mathrm{NAO}$ arises as the dominant mode of atmospheric variability explaining $60 \%$ of the simulated SLP variance versus $37 \%$ found in observations [Hurrell et al., 2003]. The standardized NAO index (Figure 3a) exhibits large interannual fluctuations superimposed over lower-frequency decadal cycles, as highlighted by the 9 year running mean of the NAO index (Figure $3 b$ ). During positive NAO+ years anomalously high surface pressures $(>2 \mathrm{hPa})$ south of $55^{\circ} \mathrm{N}$ are combined with anomalously low pressures $(<4 \mathrm{hPa})$ throughout the Arctic (Figure 3c, colors). Thus $\mathrm{NAO}+$ phases act to enhance meridional pressure gradients (Figure 3c, contours), thereby strengthening and displacing a few degrees north the westerly winds between $40^{\circ} \mathrm{N}$ and $60^{\circ} \mathrm{N}$, and weakening them between $30^{\circ} \mathrm{N}$ and $45^{\circ} \mathrm{N}$ (Figure 3d, arrows). The NAO+ northward displacement of westerly winds corresponds to negative wind 

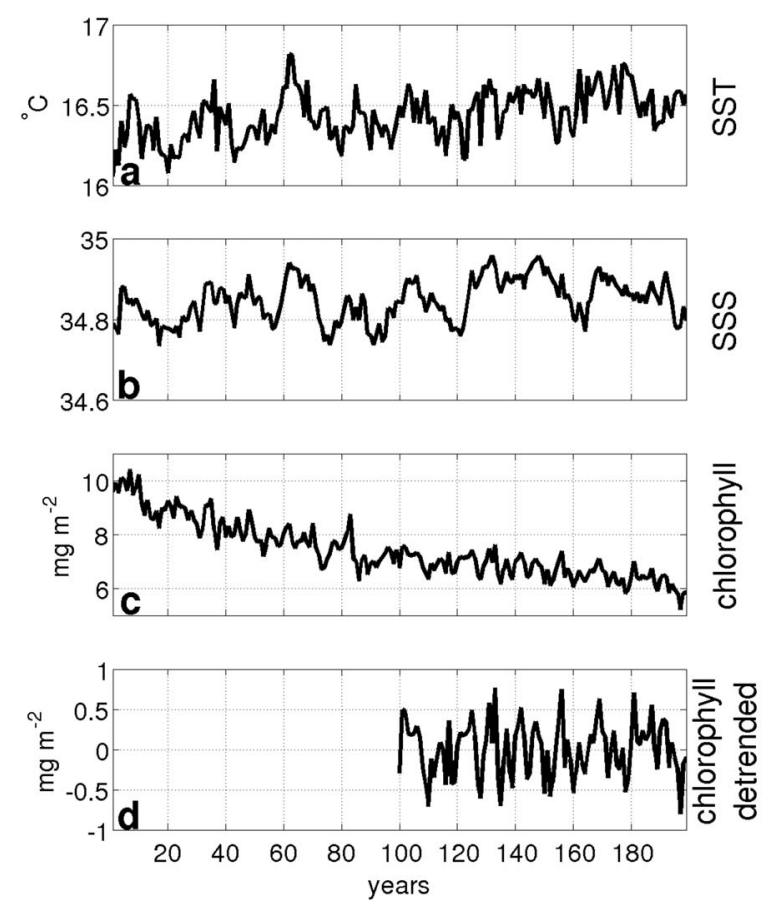

Figure 2. Annually averaged time series averaged over the North Atlantic Ocean $\left[20^{\circ} \mathrm{N}-70^{\circ} \mathrm{N}, 90^{\circ} \mathrm{W}-40^{\circ} \mathrm{E}\right]$ of the last 200 years of simulation of (a) sea surface temperature (SST) in ${ }^{\circ} \mathrm{C}$, (b) sea surface salinity (SSS) in practical salinity scale, (c) chlorophyll concentration integrated in the euphotic layer in $\mathrm{mg} \mathrm{m}^{-2}$, and (d) detrended chlorophyll concentration time series over the last 100 years of simulation.

stress curl anomalies between $35^{\circ} \mathrm{N}$ and $55^{\circ} \mathrm{N}$, and positive anomalies to the north and south (Figure $3 \mathrm{~d}$, colors).

[17] The NAO interannual persistence is investigated by comparing lagged autocorrelations of the simulated NAO index with those of the observed Hurrell's NAO index [Hurrell, 1995] in the period 1940-2009 (Figure 3e). The latter is computed as the normalized SLP differences between Lisbon, Portugal, and Stykkisholmur, Iceland (Figure 3c, stars). To maintain consistency with the length of the observational data set, model autocorrelations are computed on three different 70 year periods covering the 200 year simulation. The simulated NAO index exhibits a decorrelation time scale of 1 year, independent of the time period analyzed, which is faster with respect to the 2 year decorrelation time scale of the Hurrell's NAO index. Thus the model underestimates the persistence of the NAO atmospheric variability.

\section{Direct Response to the NAO}

\subsection{Physical Response}

[18] Figure 4 shows linear regression coefficients of simulated winter (DJFM) variables onto the NAO index (colors), and the corresponding DJFM climatologies (contours). The anomalies correspond to $\mathrm{a}+1$ standard deviation departure of the NAO index, assuming a linear response to the NAO forcing. Regression coefficients are shown only for those grid points in which the correlation coefficient between NAO index and the investigated variable is significant at $90 \%$. In response to $\mathrm{NAO}+$ wind changes, the model simulates an enhancement of ocean heat losses (Figure 4a) in the subpolar gyre ( $\sim 30 \%$ of climatology) and a decrease at middlesubtropical latitudes. These changes are mostly due to sensible and latent heat fluxes (not shown), the latter being highly correlated with evaporative losses. The northward displacement of the westerly storm track (Figure 3d) increases precipitation north of $45^{\circ} \mathrm{N}$ and reduces it below (not shown). Changes in evaporation minus precipitation (Figure $4 b$ ) are almost everywhere positive (indicating an increase in evaporation or a decrease in precipitation) except along the North American coast and in the eastern subpolar latitudes.

[19] The simulated changes in air-sea heat and freshwater fluxes in turn affect SST (Figure 4c) and SSS (Figure 4d). The direct response of SST to NAO+ winters exhibits a tripolar pattern of decreased SST at subpolar $\left(\sim 0.6^{\circ} \mathrm{C}\right)$ and tropical latitudes, and increased SST at midlatitudes, as also detected in observations [e.g., Visbeck et al., 2003]. The direct response of SSS to NAO+ winters may exceed 0.1 in magnitude (Figure 4d), and shows an increase in the subpolar gyre and in the Subtropics and a decrease south of Greenland and in the $40^{\circ} \mathrm{N}$ latitudinal belt. The simulated direct response of SST and SSS to NAO forcing occurs through the combined effect of changes in air-sea fluxes and in surface circulation (not shown), as also suggested by Visbeck et al. [2003] and Mignot and Frankignoul [2004]. In this simulation, advective contributions are particularly large south of Greenland, where anomalous southward circulation, arising as an Ekman response to wind stress curl changes, advects low SSS and SST waters southward (not shown).

[20] The simultaneous variations in SSS and SST in turn modify surface seawater density (Figure 4e) calculated using the United Nations Educational, Scientific, and Cultural Organization [1983] equation of state. During NAO+ years, surface density increases by $\sim 0.05 \mathrm{~kg} \mathrm{~m}^{-3}$ in the central subpolar gyre because of the concomitant effect of increased SSS and decreased SST, whereas it decreases off the Greenland coast because of decreased SSS, and at middle and subtropical latitudes because of increased SST. Variations in surface density are correlated with MLD changes (Figure 4f). During NAO+ years increased ocean density and wind speeds in the subpolar gyre deepen the ocean mixed layer by more

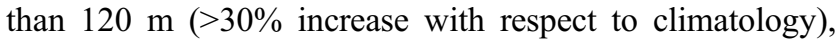
whereas they reduce it by $\sim 10 \mathrm{~m}$ between $30^{\circ} \mathrm{N}$ and $45^{\circ} \mathrm{N}$.

\subsection{Biogeochemical Response}

\subsubsection{Annual-Scale Response}

[21] Figure 5 shows linear regression coefficients of annual biogeochemical time series onto the standardized DJFM NAO index (colors), and the corresponding annual climatologies (contours). Grid points in which correlations with the NAO index are not significant at $90 \%$ are masked. Annual averages between December and November of the following year are now analyzed since, differently with respect to the physical response which is highest in winter, the peak biogeochemical response may occur at different times of the year. Biogeochemical variables are, except where otherwise stated, vertically integrated over the euphotic layer depth (hereafter ED), corresponding to the depth at which light is $1 \%$ of its surface value. Vertical integrals over the ED are computed every $6 \mathrm{~h}$ and then time averaged. The ED is 

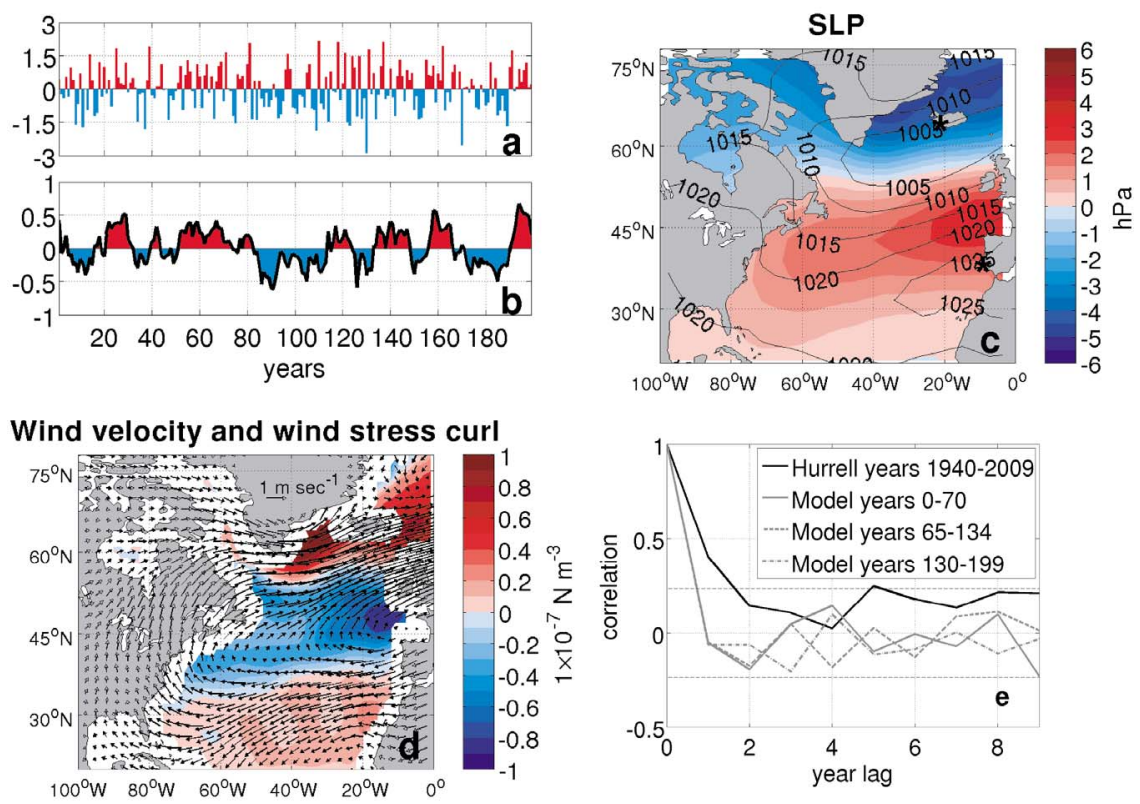

Figure 3. Simulated December-March (DJFM) North Atlantic atmospheric variability: (a) standardized $\mathrm{NAO}$ index (NAO+ in red bars and $\mathrm{NAO}-$ in blue bars), (b) nine-point running mean of the NAO index (NAO+ in red shading and NAO- in blue shading), (c) sea level pressure (hPa) climatology (contours) and linear regression coefficients onto the NAO index (colors) (black asterisks indicate the measurement sites for Hurrell's station-based NAO index), (d) linear regressions onto the NAO index of wind speed at $10 \mathrm{~m}$ height $\left(\mathrm{m} \mathrm{s}^{-1}\right)$ in arrows and of wind stress curl $\left(1 \times 10^{-7} \mathrm{~N} \mathrm{~m}^{-3}\right)$ in colors (anomalies correspond to a +1 standard deviation departure of the NAO index), and (e) decorrelation time scales for Hurrell's NAO index during years 1940-2009 (black) and for the simulated NAO index (gray lines) during three 70 year time slices (solid, dashed, and dotted lines).

itself modified by NAO fluctuations (Figure 5a), because of chlorophyll-related changes in water clarity, even though anomalies are only $1 \%-2 \%$ with respect to climatological values. Because of changes in ocean vertical mixing, simulated phosphate concentration increases by about $30 \%$ in the subpolar gyre during NAO+ years, whereas it decreases at midlatitudes (Figure 5b). Linear regressions of nitrate onto the NAO index (Figure 5c) show a similar pattern as phosphate, except in the western Subtropics where nitrate increases during $\mathrm{NAO}+$ years. This suggests that in this area phytoplankton growth may be controlled by phosphate, rather than by nitrate, availability, as also found by Vichi and Masina [2009]. In the following, phosphate will be used to diagnose nutrient changes, as the implication of phosphate as the limiting nutrient over the North Atlantic appears to be correct for this model.

[22] During NAO+ phases simulated chlorophyll concentration (a proxy of phytoplankton biomass) increases by $10 \%-20 \%$ in the subpolar gyre, in the eastern Labrador Sea, and off the northwestern African coast, whereas it decreases at middle latitudes (Figure 5d). This pattern suggests a close relationship between increased nutrient supply and increased chlorophyll concentration. The concomitant decrease in late winter light availability, expected to occur due to increased MLD (Figure 4f), appears in this model to be instead of lesser importance in determining the chlorophyll response on annual average. Changes in phytoplankton biomass in turn modify zooplankton biomass by $20 \%-30 \%$ with very similar spatial structures (not shown). Net community production (hereafter NCP), defined as the difference between primary production integrated over the euphotic zone and the respiration of the planktonic community (both phytoplankton and heterotrophic organisms such as bacteria and zooplankton), is also in turn modified. During NAO+ phases, NCP increases by about $2 \mathrm{~mol} \mathrm{C} \mathrm{m}^{-2} \mathrm{yr}^{-1}$ at subpolar latitudes (Figure $5 \mathrm{e}$ ), and decreases of about $1 \mathrm{~mol} \mathrm{C} \mathrm{m}^{-2} \mathrm{yr}^{-1}$ at middlesubtropical latitudes (i.e., $\sim 20 \%$ of climatological values), in agreement with previous modeling studies performed in the western Subtropics [Gruber et al., 2002].

[23] In response to $\mathrm{NAO}+$ winters, the model simulates a surface $\mathrm{pCO}_{2}$ decrease of up to $6 \mu \mathrm{atm}$ in the subpolar gyre and an increase of about the same magnitude at middle latitudes (Figure 5f). Several factors may affect the $\mathrm{pCO}_{2}$ response to the NAO. Dissolved inorganic carbon (hereafter DIC) concentration averaged over the first $300 \mathrm{~m}$ depth (Figure $5 \mathrm{~g}$ ) shows an increase of about $2 \mathrm{mmol} \mathrm{m}^{-3}$ at subpolar latitudes consistent with deeper mixing. This increase would be expected to increase $\mathrm{pCO}_{2}$. However, our model results show DIC changes are not large enough to contrast the decrease in subpolar surface $\mathrm{pCO}_{2}$ on annual average. Similarly, the subpolar SSS increase (Figure 4d) which would be expected to slightly increase $\mathrm{pCO}_{2}$ [Takahashi et al., 1993] does not contrast the $\mathrm{pCO}_{2}$ decrease. Changes in SST and in biological productivity appear instead to be the most relevant factors in determining the surface $\mathrm{pCO}_{2}$ response to $\mathrm{NAO}$ interannual variability. In fact, lower (higher) surface $\mathrm{pCO}_{2}$ 


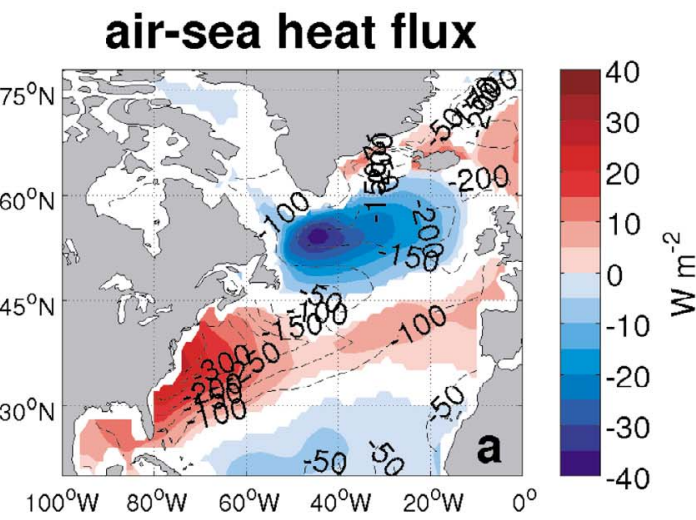

SST

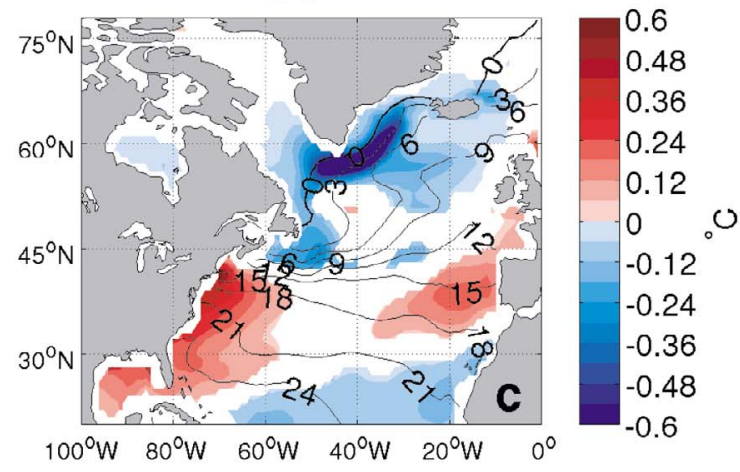

\section{sea surface density}

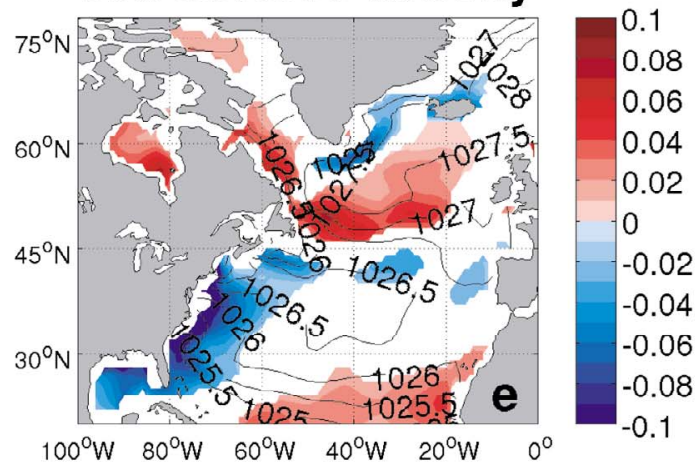

E minus $P$

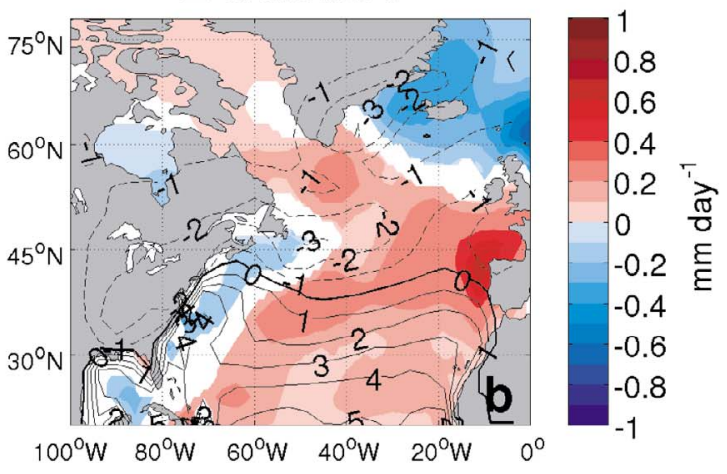

SSS

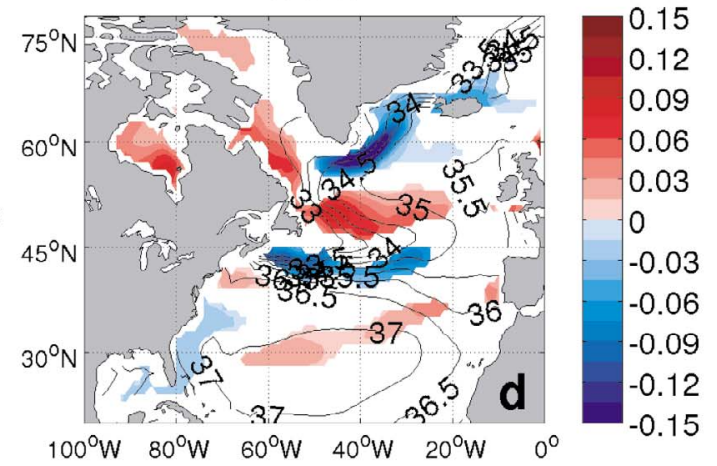

MLD

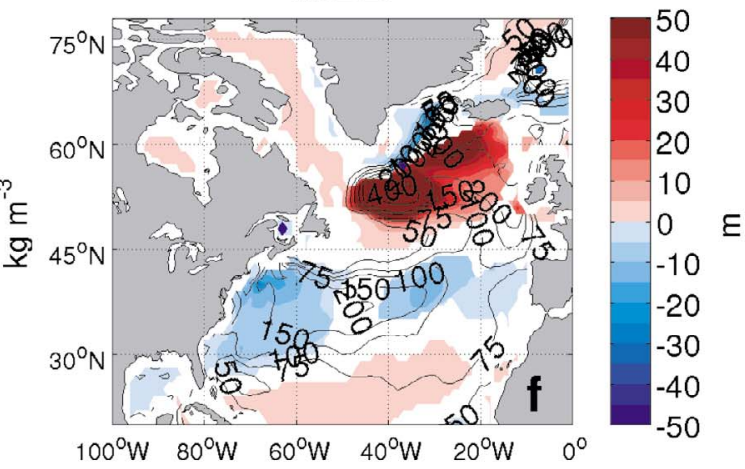

Figure 4. Colors indicate linear regression coefficients between NAO index and (December-March) DJFM anomalies of (a) net air-sea heat flux in $\mathrm{W} \mathrm{m}^{-2}$ (defined positive downward), (b) evaporation minus precipitation (E minus P) in $\mathrm{mm} \mathrm{d}^{-1}$, (c) sea surface temperature (SST) in ${ }^{\circ} \mathrm{C}$, (d) sea surface salinity (SSS) expressed in practical salinity scale, (e) sea surface density in $\mathrm{kg} \mathrm{m}^{-3}$, and (f) mixed layer depth (MLD) in $\mathrm{m}$. The anomalies, corresponding to a +1 standard deviation departure of the NAO index, are shown only on grid points in which the correlation coefficient between NAO index and the investigated variable is significant at $90 \%$. Corresponding DJFM climatologies are shown as contours.

values at subpolar (subtropical) latitudes are consistent with the overall decrease (increase) of SST (Figure 4c) and with the increase (decrease) in NCP (Figure 5e) occurring during $\mathrm{NAO}+$ years. The concomitant reduction of $\mathrm{pCO}_{2}$ and enhancement of wind speed (Figure $3 \mathrm{~d}$, arrows) causes $\mathrm{a} \sim 0.6 \mathrm{~mol} \mathrm{~m}^{-2} \mathrm{yr}^{-1}$ annual increase of the subpolar $\mathrm{CO}_{2}$ ingassing fluxes at subpolar latitudes (Figure $5 \mathrm{~h}$ ). Increased subpolar ingassing during $\mathrm{NAO}+$ years was also found in the northern North Atlantic by Olsen et al. [2003], Corbière et al. [2007], and Schuster and Watson [2007], who invoke the combination of reduced SST, increased biological uptake, enhanced wind speeds, and changes in atmospheric pressure as the likely causes.

\subsubsection{Seasonal Cycles in the Subpolar Gyre}

[24] $\mathrm{NAO}+$ and $\mathrm{NAO}-$ composites are computed by selecting years in which the standardized NAO index is higher than +1 and lower than -1 , respectively. NAO + and $\mathrm{NAO}-$ monthly seasonal cycles averaged over the subpolar area $\left[45^{\circ} \mathrm{N}-60^{\circ} \mathrm{N} ; 50^{\circ} \mathrm{W}-20^{\circ} \mathrm{W}\right]$ (black contoured box in Figure 5a) are shown in Figure 6 together with monthly cli- 




nitrate (ED)

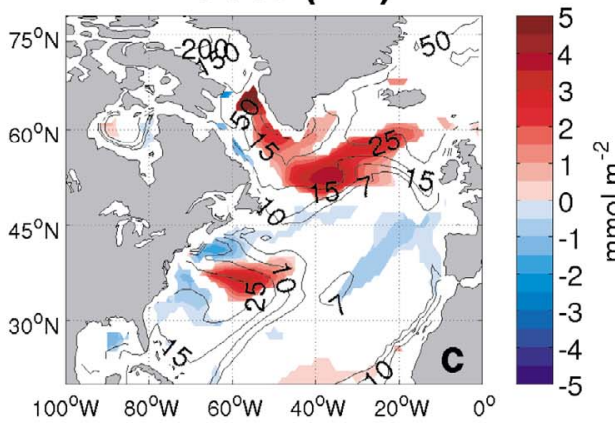

NCP (ED)



$\operatorname{DIC}(0-300 \mathrm{~m})$

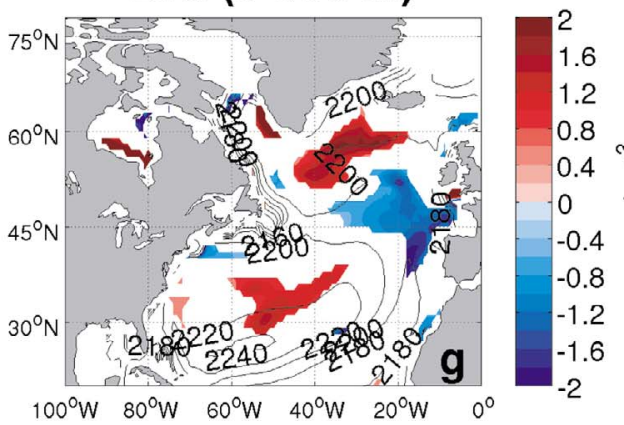

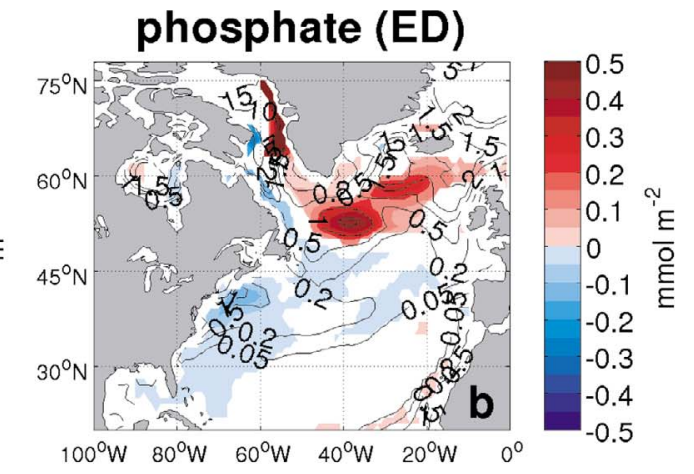

chlorophyll (ED)

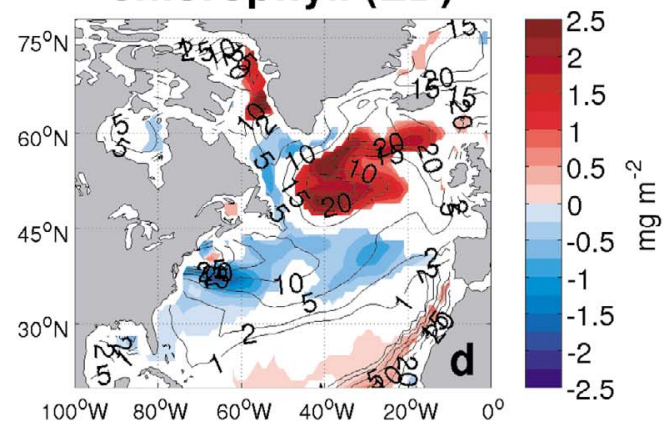

$\mathrm{pCO}_{2}$ (surface)

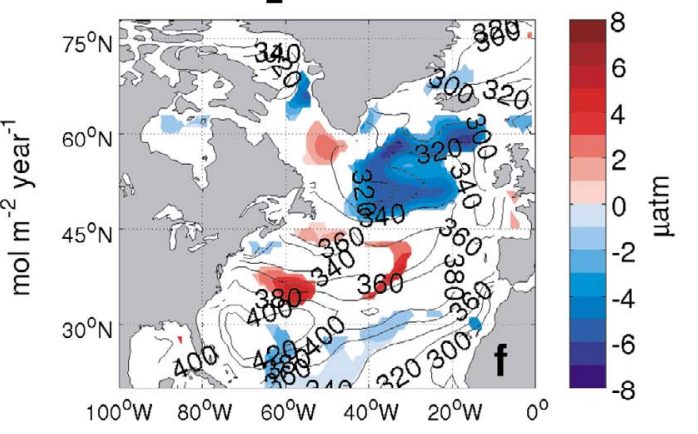

air-to-sea $\mathrm{CO}_{2}$ flux

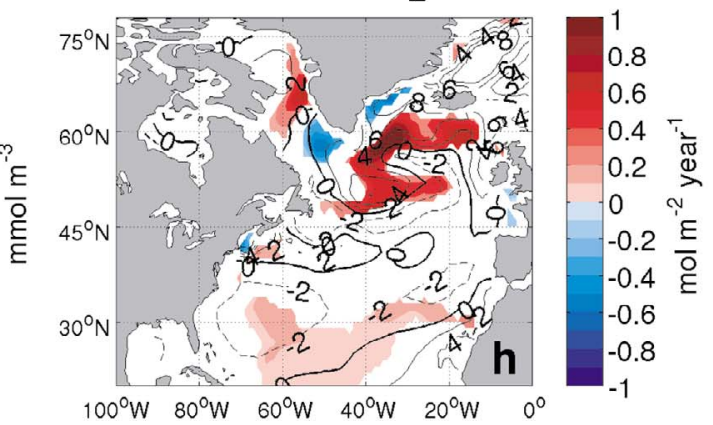

Figure 5. Colors indicate linear regression coefficients between NAO index and annual averages of (a) euphotic layer depth (ED) in $\mathrm{m}$, (b) phosphate concentration integrated in ED in $\mathrm{mmol} \mathrm{m}^{-2}$, (c) nitrate concentration integrated in ED in $\mathrm{mmol} \mathrm{m}{ }^{-2}$, (d) chlorophyll concentration integrated in ED in $\mathrm{mg} \mathrm{m}^{-2}$, (e) net community production (NCP) integrated in $\mathrm{ED}$ in $\mathrm{mol} \mathrm{C} \mathrm{m}^{-2} \mathrm{yr}^{-1}$, (f) surface $\mathrm{CO}_{2}$ partial pressure $\left(\mathrm{pCO}_{2}\right)$ in $\mu \mathrm{atm},(\mathrm{g})$ dissolved inorganic carbon (DIC) averaged over the $0-300 \mathrm{~m}$ depth interval in mmol $\mathrm{m}^{-3}$, and (h) air-to-sea $\mathrm{CO}_{2}$ flux (defined positive downward) in $\mathrm{mol} \mathrm{m}^{-2} \mathrm{yr}^{-1}$. The anomalies, corresponding to $\mathrm{a}+1$ standard deviation departure of the NAO index, are shown only on grid points in which the correlation coefficient between NAO index and the investigated variable is significant at $90 \%$. Corresponding annual climatologies are shown as contours. Figure 5 a additionally shows the area $\left[45^{\circ} \mathrm{N}-60^{\circ} \mathrm{N}, 50^{\circ} \mathrm{W}-\right.$ $\left.20^{\circ} \mathrm{W}\right]$ on which averages shown in Figure 6 are computed. 


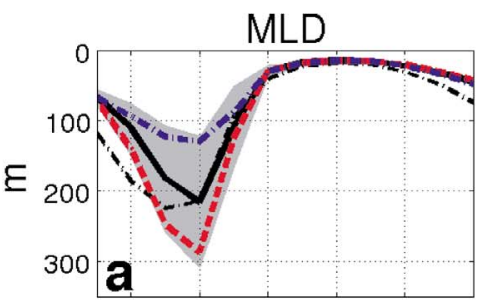

Jan Mar May Jul Sep Nov
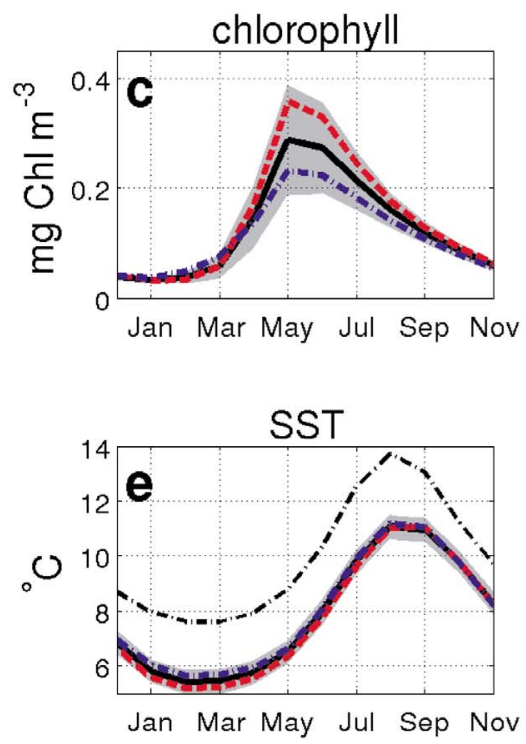
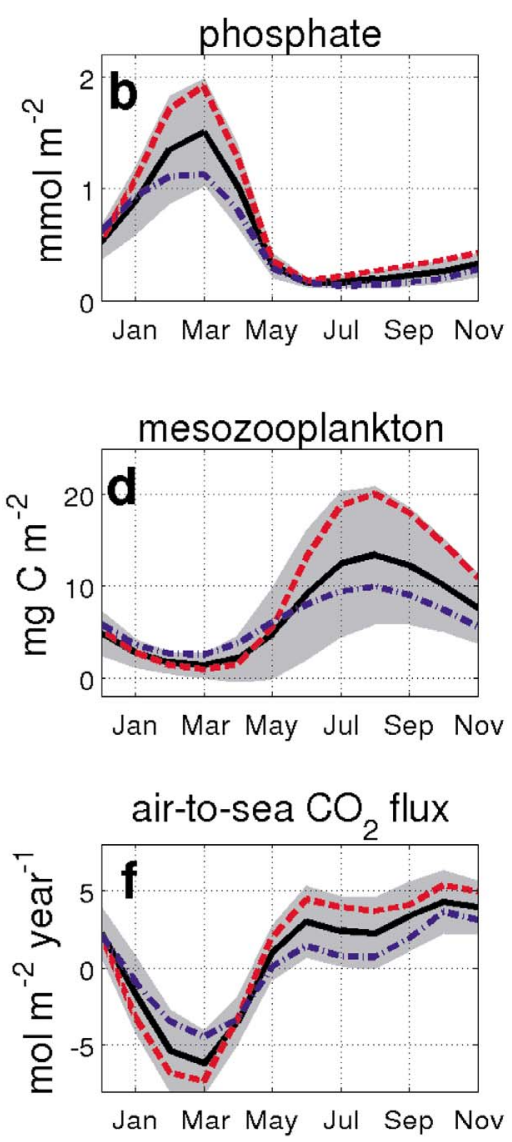

Figure 6. Climatological seasonal cycles (black), their standard deviation (gray shading), NAO+ composites (red dashed line), and NAO- composites (blue dash-dotted line), horizontally averaged over the subpolar region $\left[45^{\circ} \mathrm{N}-60^{\circ} \mathrm{N}, 50^{\circ} \mathrm{W}-20^{\circ} \mathrm{W}\right.$ ] shown in Figure $5 \mathrm{a}$ of (a) mixed layer depth (MLD) in $\mathrm{m}$ (note reversed $y$ axis) and observed climatology (dashed black line) from de Boyer Montégut et al. [2004], (b) phosphate concentration integrated in the euphotic layer depth (ED) in $\mathrm{mmol} \mathrm{m}^{-2}$, (c) chlorophyll concentration averaged in ED in $\mathrm{mg} \mathrm{m}^{-3}$, (d) mesozooplankton concentration integrated in ED in $\mathrm{mg} \mathrm{C} \mathrm{m}^{-2}$, (e) simulated SST and observed Hadley SST climatology (dashed black line) in ${ }^{\circ} \mathrm{C}$, and (f) air-to-sea $\mathrm{CO}_{2}$ flux (defined positive downward) in $\mathrm{mol} \mathrm{m}^{-2} \mathrm{yr}^{-1}$.

matologies and their standard deviation. As for section 3.2.1, the investigated variables are integrated over the ED unless otherwise stated.

[25] The subpolar MLD exhibits a climatological maximum value of $\sim 200 \mathrm{~m}$ in March which is comparable to the observational MLD estimate from de Boyer Montégut et al. [2004] averaged over the same area (Figure 6a). Since de Boyer Montégut et al. [2004] use a $0.03 \mathrm{~kg} \mathrm{~m}^{-3}$ density criterion to define the MLD, it is possible that the observed MLD may be slightly deeper than in the model which instead uses a $0.01 \mathrm{~kg} \mathrm{~m}^{-3}$ criterion. $\mathrm{NAO}+$ winters act to deepen the winter mixed layer by about $100 \mathrm{~m}$, whereas $\mathrm{NAO}-$ winters shoal the winter mixed layer of approximately the same amount. Winter NAO variability explains most of the standard deviation of MLD, a phenomenon which is likely related to the large SLP variance explained by NAO variability in the coupled model. Winter NAO forcing ceases to exert any noticeable influence on the MLD during the subsequent May-November months, when the simulated MLD stratifies up to $20 \mathrm{~m}$ and its standard deviation is highly damped. Deeper winter mixing affects phytoplankton biomass and its seasonality in two opposite ways: on one hand it reduces light availability [Sverdrup, 1953] and on the other it increases winter-spring phosphate (and nitrate) concentration in the ED (Figure 6b). The model results show that in response to a NAO+ winter, chlorophyll concentration is slightly lower than average between January and April, whereas it is $10 \%$ 20\% higher between May and August (Figure 6c). These model results thus suggest that NAO interannual fluctuations impact the seasonal cycle strength of subpolar phytoplankton, which is amplified during $\mathrm{NAO}+$ years and weakened during NAO- years. Changes in phytoplankton seasonality during $\mathrm{NAO}+$ years have delayed effects also on mesozooplankton biomass, which is lower than average up to May and higher than average during summer months (Figure 6d).

[26] The deeper-than-average winter mixing occurring during $\mathrm{NAO}+$ winters enhances the entrainment of $\mathrm{CO}_{2}-$ enriched subsurface waters toward the surface, thereby increasing subpolar $\mathrm{CO}_{2}$ outgassing fluxes in winter. However, in the following spring-summer months, lower SST (Figure 6e) and enhanced chlorophyll concentration (Figure 6c) increase subpolar $\mathrm{CO}_{2}$ ingassing fluxes. Thus the 
air-sea $\mathrm{CO}_{2}$ flux seasonal cycle is amplified during NAO+ years and reduced in NAO- years (Figure 6f). On annual average, these opposite seasonal responses of air-sea $\mathrm{CO}_{2}$ flux to the NAO give rise to a small increase $(\sim 10 \%)$ of the $\mathrm{CO}_{2}$ ingassing flux at subpolar latitudes. These results are consistent with the ship-based measurements in the subpolar gyre analyzed by Corbière et al. [2007], who also detect a reduction of the strength of the $\mathrm{CO}_{2}$ fugacity seasonal cycle in years of negative NAO. However, since in this area the simulated SST is about $2^{\circ} \mathrm{C}$ lower than in Hadley observations (Figure 6e) it is possible that the $\mathrm{CO}_{2}$ solubility in seawater may be overestimated by the model.

\subsubsection{Comparison With Observational Estimates}

[27] The simulated increase in the spring subpolar phytoplankton bloom following a NAO+ winter does not wholly agree with previous studies on the topic. In fact, whereas there is general consensus that increased mixing in the nutrientdepleted subtropical latitudes leads to higher phytoplankton biomass [Follows and Dutkiewicz, 2002; Henson et al., 2009], at subpolar latitudes chlorophyll was found to be either uncorrelated with NAO interannual fluctuations [Follows and Dutkiewicz, 2002; Barton et al., 2003] or to decrease during NAO+ years [Dutkiewicz et al., 2001; Henson et al., 2006, 2009]. The delayed development of the spring stratification, which diminishes the length of the phytoplankton growing season, was invoked as the likely cause for the chlorophyll spring reduction. In this study this issue is further investigated by computing $\mathrm{NAO}+$ composites over a 9 year time series from 1998 to 2006 of satellite SeaWiFS chlorophyll estimates [McClain, 2009]. The time series is too short to provide robust statistics, yet it may give useful information on the strengths and weaknesses of the model employed in this study. Specifically, between 1998 and 2006, the selected $\mathrm{NAO}+$ years are 1999 and 2000 (NAO index $>1$ standard deviation) and the NAO- years are 2001 and 2006 (NAO index $<-1$ standard deviation).

[28] In the spring-summer months (April-July) following a high $\mathrm{NAO}+$ winter, satellite chlorophyll anomalies (Figure 7b) show a large-scale chlorophyll decrease between $35^{\circ} \mathrm{N}$ and $45^{\circ} \mathrm{N}$, an increase between $45^{\circ} \mathrm{N}$ and $60^{\circ} \mathrm{N}$, and a decrease at high latitudes and in the Labrador Sea. The largescale features of the simulated (Figure 7a) and observed chlorophyll response to $\mathrm{NAO}+$ winters are therefore comparable, even though the satellite data are characterized by higher spatial variability than the model. This may be partly due to the fact that the satellite $\mathrm{NAO}+$ composite is performed over 2 years, whereas in the model 30 years are employed. Even though the model underestimates chlorophyll concentration in the North Atlantic basin (Figures 7a and 7b, contours), the anomalies in response to a NAO+ winter are correctly simulated (i.e., $\sim 0.1-0.2 \mathrm{mg} \mathrm{Chl} \mathrm{m}^{-3}$ ). The model captures, however, only a small part of the high-latitude decrease in spring chlorophyll in response to NAO+ winters. This is possibly due to overestimated sea ice cover (Figure 1c, black lines), a bias which persists also through March and April, or to shallower-than-observed mixing in spring (not shown).

[29] Because of the shortness of the employed SeaWiFS time series, it may be questioned whether the anomalies shown in Figure $7 \mathrm{~b}$ are indeed caused by the NAO. To tackle this issue, the variance explained by the NAO (i.e., the squared correlation coefficient times 100) is computed for the model (Figure 7c) and for the SeaWiFS data set (Figure 7d). The chlorophyll variance explained by the NAO in the SeaWiFS time series is quite patchy, as already suggested by Follows and Dutkiewicz [2002]. In addition, contrarily to the model, the maximum explained variance does not trivially match the areas of maximum chlorophyll anomalies. It is also to be remarked that in the years 1971-1975 Follows and Dutkiewicz [2002] do not find a clear relationship between meteorological forcing and spring-summer chlorophyll concentration at the Ocean Weather Station "India" $\left(59^{\circ} \mathrm{N}\right.$, $\left.15^{\circ} \mathrm{W}\right)$. These results suggest caution in attributing chlorophyll anomalies to NAO variability in such short time series.

[30] NAO+ and NAO- composite seasonal cycles are computed over the subpolar area $\left[45^{\circ} \mathrm{N}-65^{\circ} \mathrm{N}, 40^{\circ} \mathrm{W}-10^{\circ} \mathrm{W}\right]$ (thick boxes in Figures $7 \mathrm{c}$ and $7 \mathrm{~d}$ ). Similar to the model simulation (Figure 7e) at subpolar latitudes the seasonal cycle of the observed chlorophyll (Figure 7f) is amplified in response to a $\mathrm{NAO}+$ winter and weakened in response to a NAO- winter. This is in agreement with the mechanism emerging from the model results, i.e., that deeper winter mixing causes a light-limited reduction in subpolar chlorophyll in late winter and an enhanced chlorophyll bloom in spring. However, ocean color satellites are not able to retrieve data north of $\sim 50^{\circ} \mathrm{N}$ in December-January, because of the low sun angle in winter time. Thus, satellite data in those two months are likely biased by the fewer data available south of $50^{\circ} \mathrm{N}$.

[31] Figure $7 \mathrm{~g}$ shows simulated $\mathrm{NAO}+$ and NAOmonthly seasonal cycles averaged over the western subtropical area $\left[29^{\circ} \mathrm{N}-34^{\circ} \mathrm{N}, 67^{\circ} \mathrm{W}-61^{\circ} \mathrm{W}\right]$ (thin box in Figure $7 \mathrm{c}$ ), and compares them with in situ bottle data of Turner chlorophyll collected at the BATS station $\left[31^{\circ} 40^{\prime} \mathrm{N}, 64^{\circ} 10^{\prime} \mathrm{W}\right]$ (Figure 7h). The observed chlorophyll data (averaged between 0 and $150 \mathrm{~m}$ depth) are available in the years 19892005 during which the NAO+ years were 1989-1995, 1999 and 2000, and the NAO- years were 1996 and 2000. Since between 1989 and 2005 the NAO was mostly in its positive phase, the climatology is biased toward positive NAO+ phases. Despite this unbalance, the observations show that winter chlorophyll values tend to be higher during NAOwinters and slightly lower during NAO+ winters. This response is captured also by the model, even though the chlorophyll climatology is largely underestimated with respect to observed. This is due to the overly northward expansion of the oligotrophic conditions typical of the subtropical gyre (Figures 1d and 7a, contours).

\section{Lagged Response to the NAO}

[32] Figure 8 shows correlation maps between the NAO index and investigated time series shifted of 0,1 , and 2 years with respect to the NAO index. Only statistically significant correlation coefficients at $90 \%$ are shown. Lagged correlations between the NAO index and DJFM SST are shown for the model (Figures $8 \mathrm{a}-8 \mathrm{c}$ ) and for observations during the period 1931-2002 (Figures 8d-8f). Observational data sets employed here are the Hurrell NAO index [Hurrell, 1995] and the Hadley SST data set [Rayner et al., 2003]. Simulated and observed SST anomaly patterns are very similar at zero lag, and both maintain large statistically significant correlation areas in the following 2 years. Multiannual SST persistence is likely due to the winter "reemergence" of subsurface 

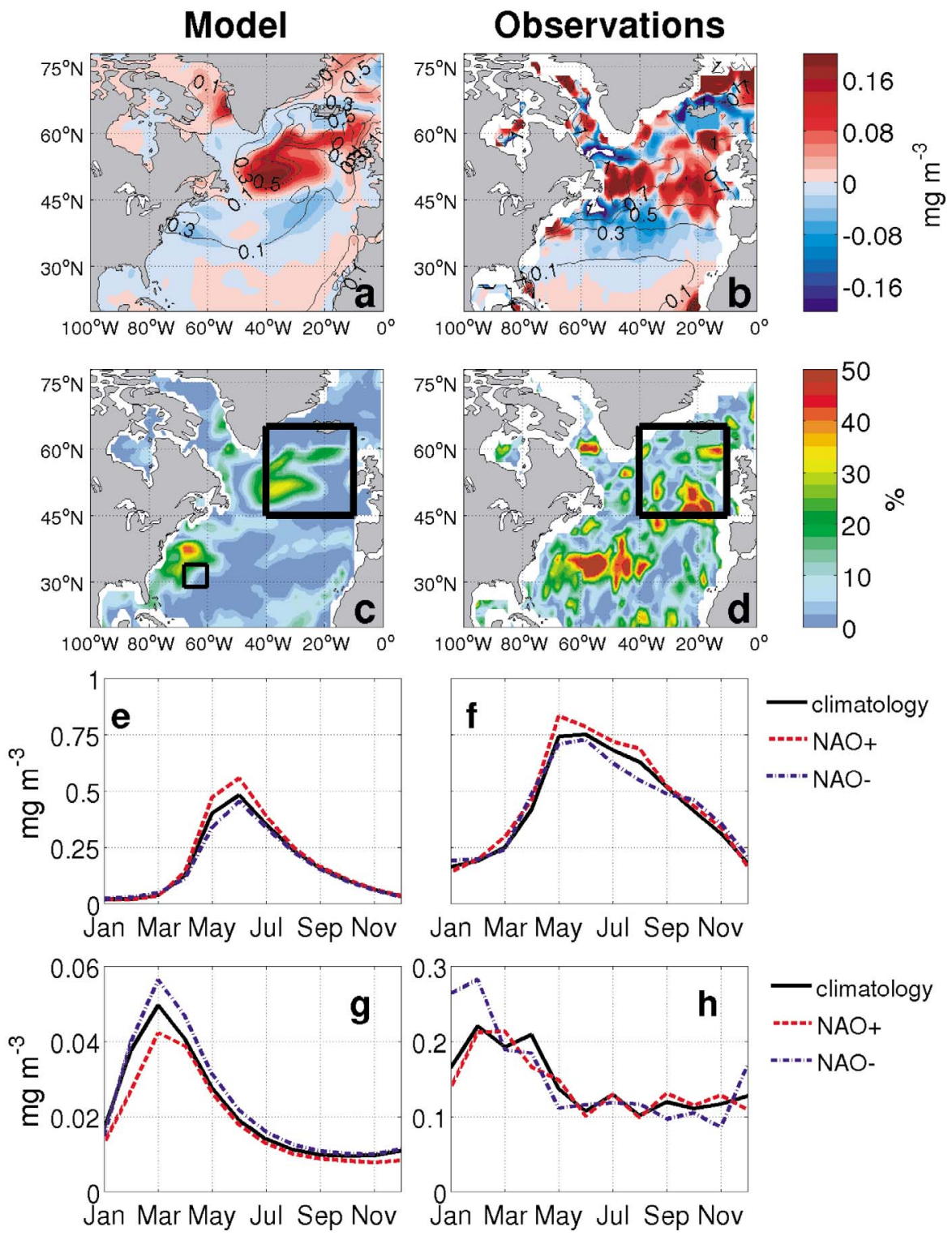

Figure 7. NAO+ chlorophyll concentration anomalies (colors) and respective climatology (contours) in $\mathrm{mg} \mathrm{m}^{-3}$ in (a) the model (average over the ED) and (b) in SeaWiFS chlorophyll estimates for the years 1998-2006; chlorophyll variance explained by the NAO in (c) the model and in (d) SeaWiFS chlorophyll estimates for the years 1998-2006; climatological chlorophyll seasonal cycles (black solid line), NAO+ composites (red dashed line), and NAO- composites (blue dash-dotted line) averaged over the subpolar domain $\left[45^{\circ} \mathrm{N}-65^{\circ} \mathrm{N}, 40^{\circ} \mathrm{W}-10^{\circ} \mathrm{W}\right]$ (thick box shown in Figures $7 \mathrm{c}$ and $7 \mathrm{~d}$ ) in (e) the model and in (f) SeaWiFS estimates; and ( $\mathrm{g}$ and $\mathrm{h}$ ) same as Figures $7 \mathrm{e}$ and $7 \mathrm{f}$ but in the BATS area for simulated chlorophyll averaged in the area $\left[29^{\circ} \mathrm{N}-34^{\circ} \mathrm{N}, 67^{\circ} \mathrm{W}-61^{\circ} \mathrm{W}\right]$ (Figure $7 \mathrm{~g}$ ) (thin box shown in Figure $7 \mathrm{c}$ ) and in situ bottle data collected at the BATS station over the period 1989-2005 (Figure 7h). Note the different $y$ axis scale in Figures $7 \mathrm{~g}$ and $7 \mathrm{~h}$.

temperature anomalies shielded in summer by shallow mixed layers, as previously suggested by Alexander and Deser [1995]. However, model and observations differ in the apparent propagation speed of positive SST anomalies close to the North Atlantic Current (hereafter NAC) in the 2 years following a NAO+ winter. As hypothesized by Sutton and Allen [1997], the propagation of SST anomalies close to the NAC possibly indicates the action of ocean mean advection.
However, as pointed out by Krahmann et al. [2001], the apparent propagation speed of SST anomalies depends not only on the ocean advection speed but also on the NAO forcing frequency. Since in the present simulation the NAO index decorrelation time scale is shorter than observed (Figure 3e), the ocean is actively forced by a more frequently alternating NAO. The simulated SST anomalies can thus be expected to propagate northeastward mainly through the 

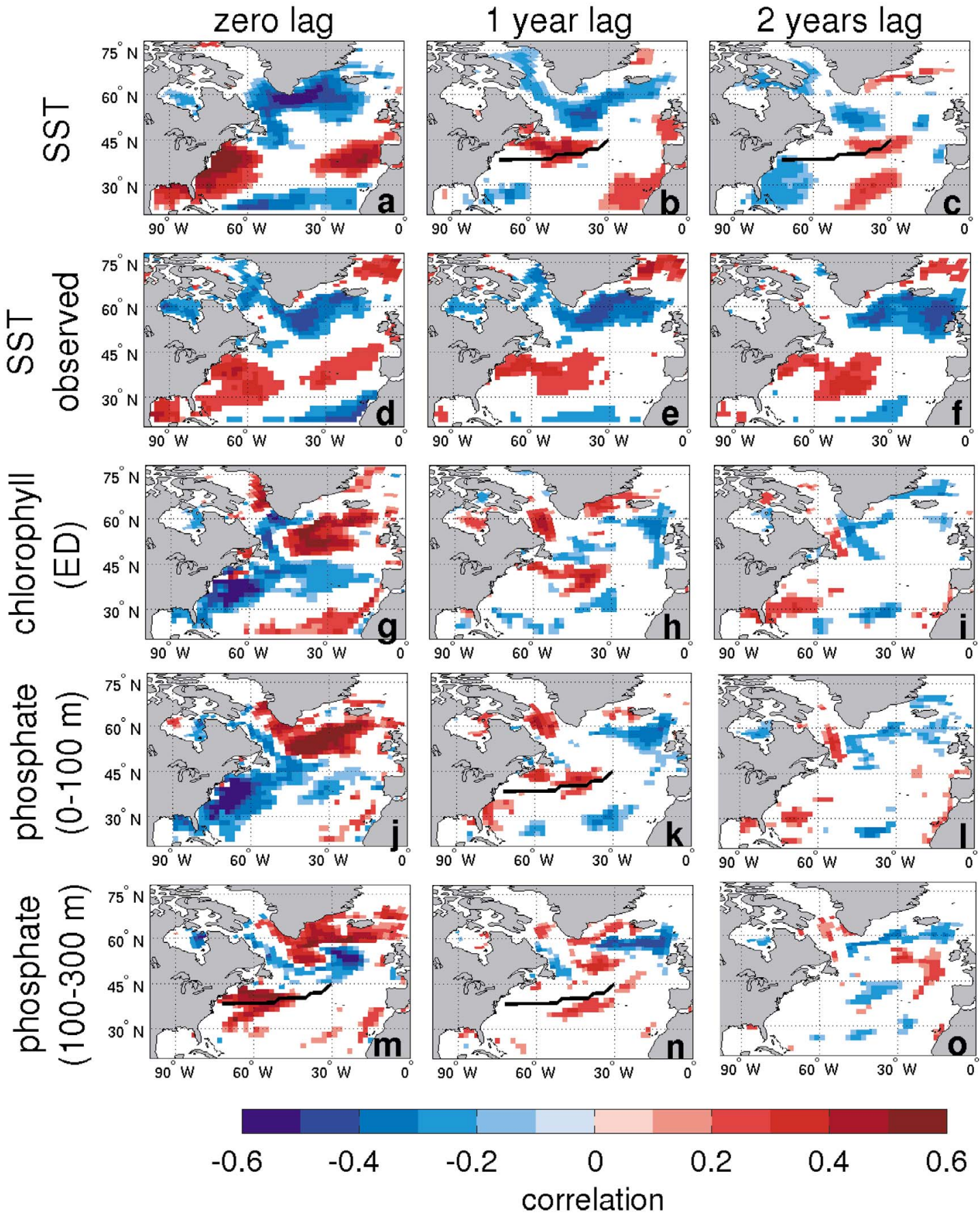

Figure 8. Lagged correlation coefficients between NAO index and (a-c) DJFM SST in the model, (d-f) DJFM SST in observations from 1931 to 2002 (using Hurrell NAO index and the Hadley SST data set), (g-i) annual chlorophyll concentration integrated over ED, $(\mathrm{j}-1)$ annual phosphate concentration integrated between 0 and $100 \mathrm{~m}$ depth, and (m-o) annual phosphate concentration integrated between 100 and $300 \mathrm{~m}$ depth. Correlations are computed with (left) no lag between NAO index and the ocean variable, (middle) 1 year lag, and (right) 2 years lag. Only correlation coefficients which are statistically significant at a $90 \%$ confidence level are shown (i.e., $>0.17$ for the model and $>0.2$ for observations). Figures $8 b, 8 \mathrm{c}, 8 \mathrm{k}$, $8 \mathrm{~m}$, and $8 \mathrm{n}$ additionally show the NAC path used in Figure 9.

NAC advection speed instead of being actively forced by a NAO of persistent sign, as in observations.

[33] Compared to SST, simulated chlorophyll concentration integrated in the ED shows weaker memory in the 2 years following a high NAO index winter (Figures $8 \mathrm{~g}-8 \mathrm{i}$ ) as also found in Continuous Plankton Recorder measurements analyzed by Barton et al. [2003]. This weak memory may be due to the fact that (1) nutrient variability is mainly controlled by vertical mixing which is governed by high-frequency atmospheric fluctuations and (2) nutrients are almost completely 

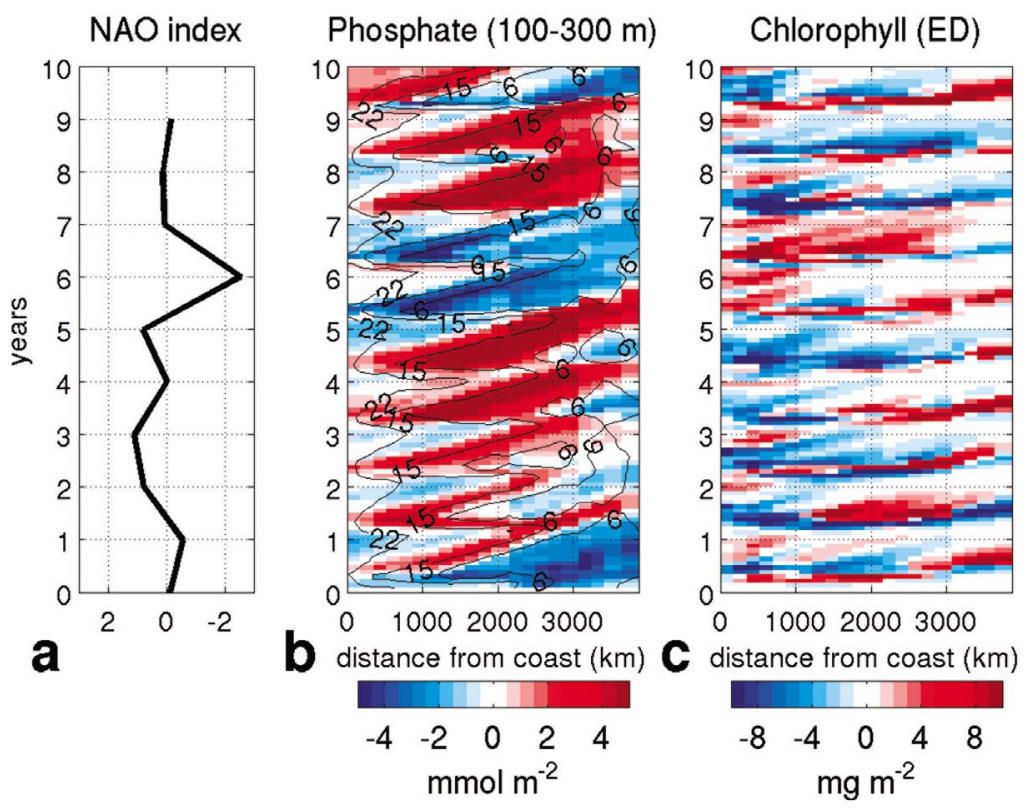

Figure 9. (a) NAO index for the representative years 165-174. Hovmöller diagrams (years 165-174) of monthly anomalies of (b) phosphate concentration integrated between 100 and $300 \mathrm{~m}$ depth in mmol m $\mathrm{m}^{-2}$ and (c) chlorophyll concentration integrated in the ED in $\mathrm{mg} \mathrm{m}^{-2}$. Figure $9 \mathrm{~b}$ additionally shows in contours the absolute values of the phosphate concentration integrated between 100 and $300 \mathrm{~m}$ depth $\left(\mathrm{mmol} \mathrm{m}^{-2}\right)$. The variables are shown as a function of distance $(\mathrm{km})$ from the American coast along the North Atlantic Current path shown in Figures 8b, 8c, 8k, 8m, and $8 \mathrm{n}$.

consumed in spring-summer (Figure 6b) thereby "resetting" the biogeochemical system at each new summer. However, a large area of significant correlations between NAO index and chlorophyll occurs in the central North Atlantic with a lag of 1 year (Figure $8 \mathrm{~h}$ ). The following mechanism is suggested to be at work. The model shows that shallower (deeper) mixing occurring during a NAO $+\left(\mathrm{NAO}^{-}\right)$winter in the western subtropical Atlantic (Figure 4f) is associated with lower (higher) phosphate concentrations in the first hundred meters depth (Figure 8j) and higher (lower) phosphate concentrations below the ED in the representative 100-300 m depth layer (Figure $8 \mathrm{~m}$ ). This suggests that changes in the MLD, which in this area reaches $\sim 150 \mathrm{~m}$ depth on annual average (Figure 1c), can modify the subsurface nutrient reservoirs. In fact when the MLD is deeper than average, more nutrients are conveyed to the euphotic depth and fewer nutrients remain in the 100-300 m layer, whereas the converse occurs when MLD is shallower than average. We hypothesize that subsurface nutrient anomalies are then advected at subsurface levels by the northeastward NAC, emerge in the ED during the subsequent deep winter mixing, and generate the detected chlorophyll increase at middle latitudes with 1 year lag. A similar mechanism was hypothesized by Palter et al. [2005] using observations collected within the North Atlantic Subtropical Mode Waters.

[34] To give further substance to this hypothesis, the propagation of properties along the NAC is analyzed. The NAC path is identified by selecting the grid points of simulated maximum current velocity in the first $300 \mathrm{~m}$ depth (the path is shown in Figures 8b, 8c, 8k, 8m, and 8n). Monthly anomalies of phosphate concentration integrated between
100 and $300 \mathrm{~m}$ depth and of ED chlorophyll are defined by subtracting monthly climatologies from the detrended times series. Figure 9 shows, as a representative example, the resulting anomalies along the NAC path for a 10 year time slice (years 165-174 of the analyzed 200 year time series). Subsurface phosphate anomalies in the western part of the basin show an overall correspondence with the NAO index (Figure 9a); that is, NAO+ (NAO-) winters are generally associated with positive (negative) subsurface phosphate anomalies in spring. To understand better the mechanisms behind this response, Figure $9 \mathrm{~b}$ additionally shows the absolute values of the phosphate monthly concentrations integrated between 100 and $300 \mathrm{~m}$ depth (contours). These are seasonally lower in spring due to the fact that deeper spring mixing $(>100 \mathrm{~m})$ entrains more phosphate in the euphotic layer and reduces it in the 100-300 m depth layer. This result agrees with other studies conducted in near areas [Palter et al., 2005] suggesting that North Atlantic Subtropical Mode Waters are poor in nutrients at the time they are formed. During NAO+ (NAO-) years, mixing is shallower (deeper) than average in the western subtropical North Atlantic (Figure 4f), thereby enhancing (reducing) the subsurface nutrient reservoir. The propagation speed of the subsurface phosphate anomalies along the NAC path is computed by dividing the distance covered by the anomaly ( $\sim 3000 \mathrm{~km})$ by the required time span $(\sim 12-15$ months). This yields a propagation speed of $0.08-0.09 \mathrm{~m} \mathrm{~s}^{-1}$ which agrees with the mean NAC speed $\left(0.08 \mathrm{~m} \mathrm{~s}^{-1}\right)$ over the selected path. The proposed emergence mechanism of phosphate anomalies along the NAC is a biogeochemical extension to the SST "reemergence" hypothesis by Alexander and Deser [1995] 



Figure 10. (a) Linear regression coefficients between the 9 year running mean of the NAO index (Figure $3 b$ ) and 9 year running means of DJFM sea surface height (SSH) in colors $(\mathrm{cm})$ and horizontal currents averaged between 0 and $300 \mathrm{~m}$ in arrows $\left(\mathrm{cm} \mathrm{s}^{-1}\right)$. We show only grid points in which the correlation coefficients between the 9 year running mean of the NAO index and the investigated variables are significant at $90 \%$. Area-weighted standard deviations over the North Atlantic basin $\left[25^{\circ} \mathrm{N}-75^{\circ} \mathrm{N}, 80^{\circ} \mathrm{W}-0^{\circ}\right]$ of the NAO anomalies of (b) heat fluxes $\left(\mathrm{W} \mathrm{m}^{-2}\right)$ and (c) freshwater fluxes $\left(\mathrm{mm} \mathrm{d}^{-1}\right)$ due to air-sea fluxes (blue) and ocean advection (red) on interannual and decadal time scales. Fluxes are averaged between the surface and $300 \mathrm{~m}$ depth.

where, in addition to the mixed layer dynamics, the advection of anomalies by the mean flow is also considered.

[35] Positive subsurface phosphate anomalies in the western part of the basin occur in concomitance with negative chlorophyll anomalies in the ED (Figure 9c). A year later positive chlorophyll anomalies occur some $2000 \mathrm{~km}$ further downstream along the NAC. These positive chlorophyll anomalies are colocated with the phosphate anomalies propagating below the ED. The emergence of the phosphate anomalies into the ED could therefore arguably be one of the reasons behind the positive chlorophyll anomalies found a year after downstream of the original negative chlorophyll anomalies off the North American coast. It is instead excluded that the alternating sign of the chlorophyll anomalies is due to a change of sign of the NAO index (Figure 9a). This hypothesized mechanism is not visible in SeaWiFS chlorophyll estimates for the years 1998-2006 (not shown). However, it could be argued that an analysis of lagged correlations can hardly be significant in a 9 year time series, as many other mechanisms unrelated to the NAO may "obscure" the lagged chlorophyll signal caused by the NAO.

\section{Decadal Response to the NAO}

[36] The simulated decadal response to the NAO is examined by regressing 9 year running means of the investigated variables onto the 9 year running mean of the NAO index shown in Figure 3b (for the in-phase response) and onto its derivative (for the in-quadrature response, i.e., the transition between one decadal NAO phase and the other). Hereafter "decadal response" will refer to the behavior emerging after having applied a 9 year running mean. Figure 10a shows the decadal NAO+ anomalies of DJFM sea surface height (SSH) and DJFM 0-300 m horizontal ocean circulation. Linear regression coefficients are shown only for those grid points in which the correlation coefficient with the decadal NAO index is significant at $90 \%$. As already found in previous studies [Esselborn and Eden, 2001; Marshall et al., 2001], ocean circulation responds to anomalous $\mathrm{NAO}+$ wind stress curl forcing (Figure 3d, colors) by increasing the heat and mass convergence toward middle latitudes. As a result, this model simulates a SSH increase (up to $1 \mathrm{~cm}$ ) between $35^{\circ} \mathrm{N}$ and $45^{\circ} \mathrm{N}$ which is geostrophically adjusted to an anticyclonic circulation anomaly (the "inter gyre-gyre" circulation identified by Marshall et al. [2001]). This causes an enhancement and a northward displacement of the NAC [Curry and McCartney, 2001; Eden and Jung, 2001; Frankignoul et al., 2001] and anomalous southward motion in the northeastern Atlantic to close the "inter gyre-gyre" circulation [Bersch, 2002; Herbaut and Houssais, 2009]. At subpolar latitudes a $1 \mathrm{~cm} \mathrm{SSH}$ drop is associated with a spin-up of $0.1-$ $0.2 \mathrm{~cm} \mathrm{~s}^{-1}$ of the subpolar gyre circulation [Haekkinen and Rhines, 2004; Böning et al., 2006; Lohmann et al., 2009].

[37] It is suggested that on decadal time scales changes in ocean dynamics may become increasingly relevant in generating heat and freshwater flux anomalies. The relative role of air-sea versus advective fluxes at decadal time scales is investigated in this model by computing area-weighted standard deviations over the North Atlantic basin $\left[15^{\circ} \mathrm{N}-\right.$ $\left.78^{\circ} \mathrm{N}, 90^{\circ} \mathrm{W}-0^{\circ}\right]$ of anomalies in air-sea fluxes (heat and freshwater) and in advective fluxes (sum of zonal, meridional and vertical components) averaged between the surface and $300 \mathrm{~m}$ (Figures $10 \mathrm{~b}$ and $10 \mathrm{c}$ ). On interannual time scales, airsea heat flux anomalies are higher than advective heat flux anomalies whereas on decadal time scales the situation is reversed, as also hypothesized by Eden and Jung [2001] and Visbeck et al. [2003]. For freshwater fluxes the advective contribution is always higher than the air-sea flux contribution, at both interannual and decadal time scales, as also seen at the ocean surface by Mignot and Frankignoul [2004].

[38] Changes in heat and freshwater fluxes in response to decadal NAO variability generate temperature and salinity anomalies at the ocean surface (Figure 11). DJFM SST (Figure 11a) and DJFM SSS (Figure 11c) anomalies in phase with decadal $\mathrm{NAO}+$ are $\sim 50 \%$ of their interannual counterparts and show a decrease at subpolar latitudes and an increase between $40^{\circ} \mathrm{N}$ and $45^{\circ} \mathrm{N}$; in addition, a large freshening occurs in the eastern part of the basin. The structure and 



Figure 11. Colors indicate linear regression coefficients of 9 year running means of DJFM ocean variables (left) onto the 9 year running mean of the NAO index (in-phase response to NAO+) and (right) onto its derivative changed of sign (in-quadrature response to NAO+). (a and b) SST anomalies (colors) and climatology (contours) in ${ }^{\circ} \mathrm{C}$, (c and d) sea surface salinity (SSS) anomalies (colors) and climatology (contours), and (e and f) mixed layer depth (MLD) anomalies (colors) in $m$ and February-April sea ice cover anomalies (contours) in \%. We show only grid points in which the correlation coefficients between the 9 year running mean of the NAO index and the investigated variables are significant at $90 \%$.

magnitude of the simulated anomalies are in general agreement with previous studies [Visbeck et al., 1998; Eden and Jung, 2001; Bersch, 2002; Herbaut and Houssais, 2009; Lohmann et al., 2009] and indicate a relevant role of ocean advection, in addition to local forcing by air-sea fluxes, in determining the decadal ocean response to the NAO. Positive SST and SSS anomalies in phase with decadal NAO+ phases could in fact be actively generated by the intensification and northward shift of the NAC, and negative SST and SSS anomalies could be produced by the spin-up of the subpolar gyre. The large freshening of the eastern part of the basin may be due to (1) the increase in southward ocean motion which would reduce subtropical salinity inputs into the eastern subpolar gyre (as shown by Herbaut and Houssais [2009] and Frankignoul et al. [2009]) and to (2) the advection of SSS negative anomalies by the mean circulation (Figure $1 b$ ). In this area the mean ocean velocity is $\sim 0.01 \mathrm{~m} \mathrm{~s}^{-1}$ and would thus horizontally advect the anomalies over a distance of $500-1000 \mathrm{~km}$ in $2-3$ years. It is possible that the different decadal response of SST and SSS in the eastern North Atlantic is due to the stronger action of air-sea fluxes on the SST rather than on the SSS anomalies (Figures 10b and $10 \mathrm{c})$.

[39] The winter MLD in phase with decadal NAO+ (Figure 11e) shows a deepening in the central subpolar gyre. This causes an annually averaged $10 \%-20 \%$ increase of ED-integrated phosphate concentration (Figure 12a), as also seen on interannual time scales (Figures 4 and 5). In the eastern part of the basin the decadal response of MLD to NAO+ exhibits instead a shoaling, which consistently reduces the nutrient supply into the ED. This MLD shoaling does not arise on interannual time scales as it critically depends on the advective freshwater inputs occurring on decadal time scales (Figure 11c). The fairly strong phosphate anomalies found in 

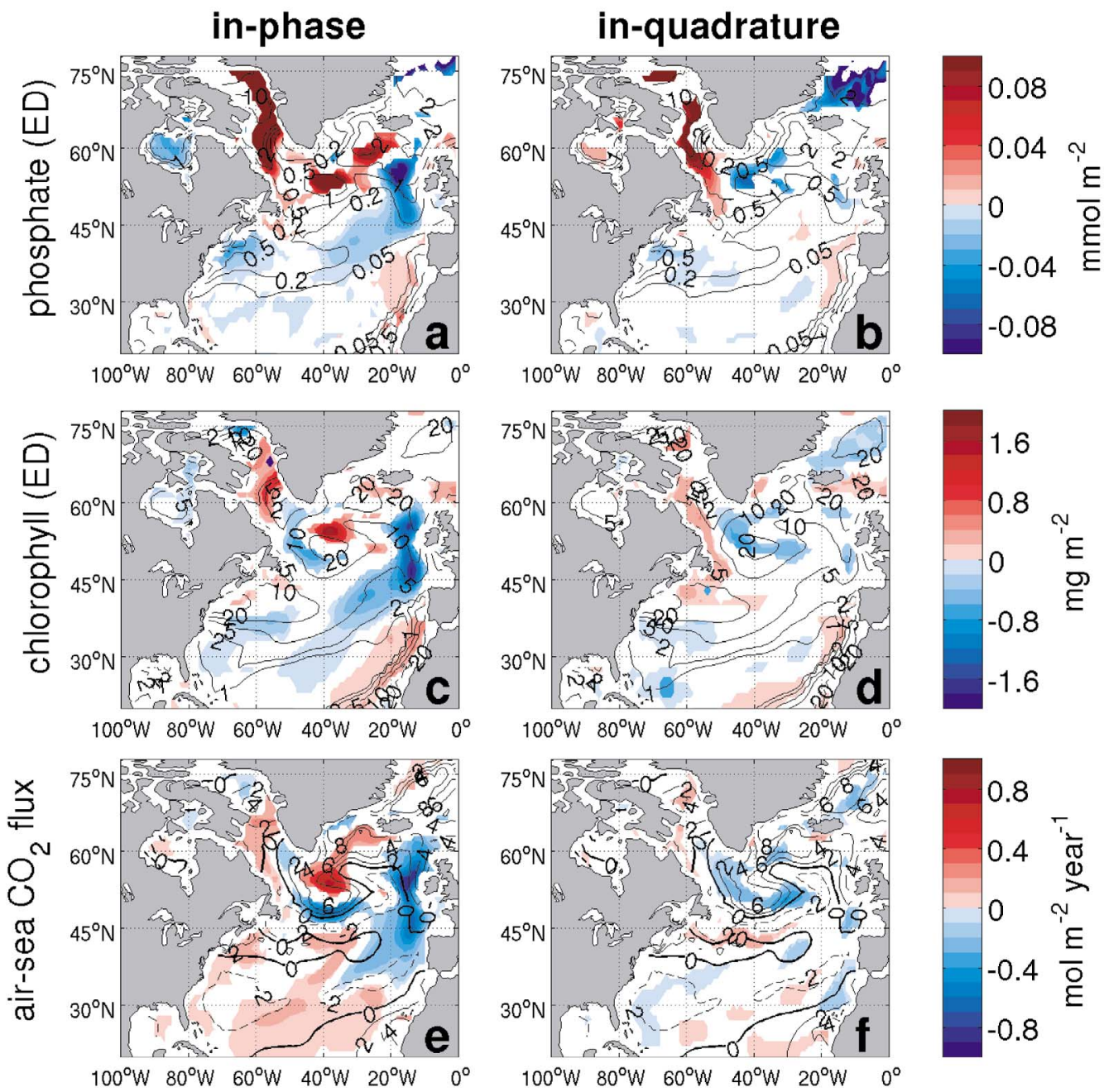

Figure 12. Colors indicate linear regression coefficients of 9 year running means of annual biogeochemical variables (left) onto the 9 year running mean of the NAO index (in-phase response to NAO+) and (right) onto its derivative changed of sign (in-quadrature response to $\mathrm{NAO}+$ ). Corresponding annual climatologies are shown as contours. (a and b) Phosphate concentration integrated in the euphotic depth (ED) in mmol $\mathrm{m}^{-2}$, (c and d) chlorophyll concentration integrated in ED in $\mathrm{mg} \mathrm{m}^{-2}$, and (e and f) air-to-sea $\mathrm{CO}_{2}$ flux (defined positive downward) in $\mathrm{mol} \mathrm{m}^{-2} \mathrm{yr}^{-1}$. We show only grid points in which the correlation coefficients between the 9 year running mean of the NAO index and the investigated variables are significant at $90 \%$.

response to decadal $\mathrm{NAO}+$ in the Labrador Sea are probably due to increased southward ocean circulation (Figure 10a) advecting toward south high climatological nutrient values simulated by the model in the northern Labrador Sea (Figure 12a, contours). World Ocean Atlas 2009 observations also show rather high phosphate climatological values in the northern Labrador Sea [Garcia et al., 2010]. However, since data coverage is very limited in this region, it is difficult to prove whether these model results are confirmed by the observational data set.

[40] During NAO+ decadal phases, simulated chlorophyll concentration (Figure 12c) increases in the central subpolar gyre and in the northern Labrador Sea, whereas it decreases in the eastern North Atlantic, in the southern Labrador Sea, and in the southern part of the subpolar gyre. The simulated chlorophyll increase in the central subpolar gyre can be traced back to the increase in mixing (Figure 11e) and in phosphate concentrations (Figure 12a) caused by increased ocean heat losses to the atmosphere. The simulated chlorophyll increase in the northern Labrador Sea is possibly linked to the increased southward advection of nutrients. The simulated chlorophyll decrease in the eastern North Atlantic is related to the reduction in mixing and phosphate concentrations caused by the salinity decrease. The simulated chlorophyll decrease in the southern Labrador Sea, associated to neither MLD nor phosphate changes, could be related to the $2 \%-6 \%$ increase in February-April sea ice cover during NAO+ decadal phases (Figure 11e, contours) which would lower light availability for phytoplankton spring growth. The low chlorophyll anomaly could then be advected eastward along the subpolar gyre thereby reducing chlorophyll concentrations in the southern subpolar gyre. All together, the spatial redistribution of chlorophyll concentration in response to decadal $\mathrm{NAO}+$ phases leads to a slight northward shift of its subpolar maximum. 


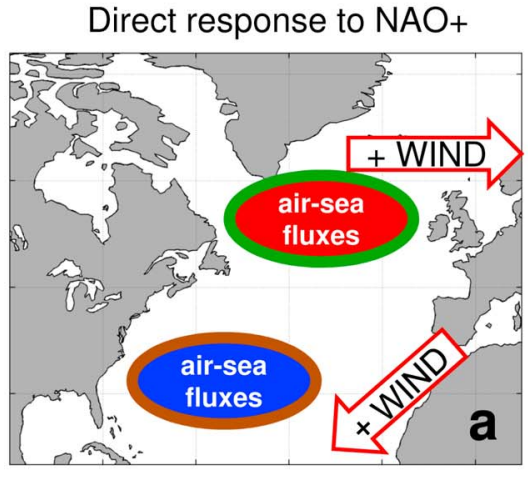

Decadal response to $\mathrm{NAO}+$

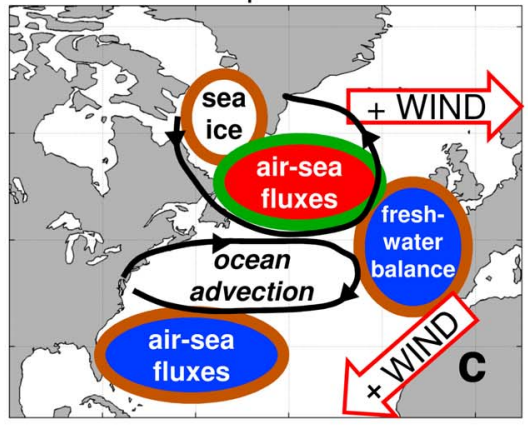

Lagged response to $\mathrm{NAO}+$

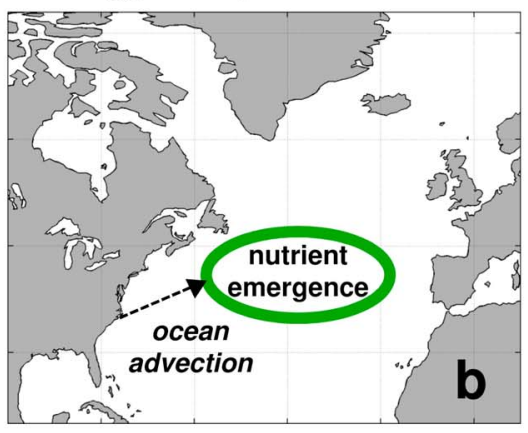

Mixed layer deepening

Mixed layer shoaling

Chlorophyll increase

Chlorophyll decrease

Wind strengthening

.M Mean circulation

$\rightarrow$ Circulation change

Figure 13. Schematic representation of (a) direct (interannual), (b) lagged, and (c) decadal response of chlorophyll to NAO+ forcing as emerging from our modeling results. Red (blue) circles indicate MLD increases (decreases), green (brown) contours indicate chlorophyll increases (decreases), red arrows indicate wind strengthening, the black dashed arrow indicates mean circulation, and black solid arrows indicate circulation changes. The text describes the mechanisms responsible for chlorophyll changes.

[41] The air-to-sea $\mathrm{CO}_{2}$ flux anomalies in phase with decadal NAO+ forcing (Figure 12e) show an increase in the central subpolar gyre and a decrease in the southern subpolar gyre and in the eastern middle latitudes. The similarity of the pattern between $\mathrm{CO}_{2}$ flux anomalies and chlorophyll anomalies suggests a close relationship between the two variables. In this model, decadal changes in biological $\mathrm{CO}_{2}$ uptake thus appear to play a relevant role in determining decadal changes in air-sea $\mathrm{CO}_{2}$ fluxes, as also seen on interannual time scales (Figure 5). The concomitant decreases in SST and SSS in the subpolar gyre are also consistent with an increase of the $\mathrm{CO}_{2}$ ingassing fluxes. In the eastern middle latitudes, the reduction of chlorophyll and the increase in SST both conjure to increase $\mathrm{pCO}_{2}$ values (not shown) and thus to reduce the ingassing of $\mathrm{CO}_{2}$ (or to increase its outgassing).

[42] During the transition from a NAO+ to a NAO- phase, the NAO atmospheric forcing is close to zero and any in-quadrature ocean anomaly (Figures 11 (right) and 12 (right)) must be driven by nonlocal mechanisms. In-quadrature SST (Figure 11b) and SSS (Figure 11d) anomalies show significant ocean memory especially close to the NAC path. This is possibly due to delayed heat convergence from the slow ocean circulation adjustment to decadal $\mathrm{NAO}+$ forcing, as also suggested by Visbeck et al. [1998] and Eden and Jung [2001]. Differently with respect to SST and SSS, the model simulates very low in-quadrature MLD anomalies (Figure 11f), indicating weak MLD memory of the previous NAO+ decadal phase. Similarly, the model simulates weak decadal memory also for biogeochemical vari- ables (Figure 12, right) which are mainly related to MLD variability.

\section{Summary and Discussion}

[43] In this study a coupled ocean-atmosphere model containing interactive marine biogeochemistry was used to analyze interannual, lagged, and decadal marine biogeochemical responses to the North Atlantic Oscillation (NAO), the primary mode of atmospheric variability in the North Atlantic sector. A relevant result emerging from this study is that the mechanisms responsible for the NAO-marine biogeochemistry interaction differ according to the time scale considered, as schematically summarized in Figure 13.

[44] 1. On interannual time scales (Figure 13a) local changes in vertical mixing, caused by modifications in air-sea heat and freshwater fluxes, are the main driver of marine biogeochemical variability through light and nutrient limitation mechanisms. In particular, winters of deeper mixing give rise to a $10 \%-20 \%$ chlorophyll increase on annual average at both subtropical and subpolar latitudes. At subpolar latitudes deeper-than-average mixing occurring during $\mathrm{NAO}+$ years causes an amplification of the chlorophyll seasonal cycle due to the combined action of reduced sunlight availability in late winter, and a higher chlorophyll bloom in the subsequent spring fueled by higher winter nutrient supply.

[45] 2. Following a high NAO index year, biogeochemical properties retain some lagged significant correlations with the NAO close to the North Atlantic Current (NAC) path 
(Figure 13b). It is suggested that shallower-than-average MLD in the western part of the basin during NAO+ phases causes an increase in subsurface nutrient reservoirs. The subsurface nutrient anomalies are subsequently advected eastward with speeds typical of the NAC. It is hypothesized that the emergence of the subsurface nutrient anomalies into the euphotic layer in the following year may enhance the downstream chlorophyll concentrations at midlatitudes with 1 year lag.

[46] 3. On decadal time scales (Figure 13c), the slow ocean circulation adjustment to decadal $\mathrm{NAO}+$ wind changes causes a spin-up of the subpolar gyre circulation which modifies the heat and freshwater advective fluxes. Decadal changes in advection combine with local mixing and sea ice variations to produce a basin redistribution of biogeochemical properties. In particular, decadal changes in nutrient supply and in sunlight availability cause a slight northward shift of the chlorophyll subpolar maximum and a reduction of chlorophyll in the eastern part of the basin.

[47] It has been shown that the coupled model is affected by a number of biases with respect to observations. These biases fall in the range of other coupled climate model included in the IPCC Fourth Assessment Report [Randall et al., 2007] and it is relevant to evaluate how they may affect the conclusions obtained from this study. The comparison with a 9 year satellite SeaWiFS chlorophyll time series and with in situ data collected at BATS helped to assess to which extent the results from this study are reliable. For instance, this simulation shows that in the western Subtropics deeper mixing occurring during NAO- years leads to higher chlorophyll concentrations. This result is consistent with the analyzed satellite and in situ observations and with previous studies [Follows and Dutkiewicz, 2002]. However, the amplitude of the NAO chlorophyll anomalies is underestimated, due to the overly northward expansion of oligotrophic conditions typical of the subtropical gyre. At subpolar latitudes the modeling results show that deeper winter mixing leads to slightly lower phytoplankton biomass in late winter and $10 \%-20 \%$ higher subpolar phytoplankton in spring. This result appears consistent with the SeaWiFS satellite chlorophyll estimates. However, different to this study, at latitudes higher than $\sim 55^{\circ} \mathrm{N}$, SeaWiFS estimates show a decrease in spring chlorophyll in years of deeper mixing, consistent with the findings of Barton et al. [2003] and Henson et al. [2006]. This discrepancy between the model and the observations is likely related to the overestimated extent of simulated sea ice cover at high latitudes, and to the absence in the model of intermittent restratification in spring, due to the coarse spatial resolution of the coupled model.

[48] The proposed mechanism of emergence of subsurface phosphate anomalies along the NAC is a biogeochemical extension of the SST "reemergence" hypothesis by Alexander and Deser [1995] where, in addition to the mixed layer dynamics, the advection of anomalies by the mean flow is also considered. This mechanism is in agreement with the observational study by Palter et al. [2005] suggesting that interannual variability of local mixing affects the subsurface nutrient properties and the downstream productivity of North Atlantic Subtropical Mode Waters. However, some model caveats should be kept in mind. First, the fast decorrelation time scales of the NAO index may enhance the apparent propagation speed of the property anomalies along the NAC path. Second, the spatial displacement of the simulated NAC probably gives rise to spatial shifts of the subsurface nutrient advection as well.

[49] The third conclusion, regarding the decadal chlorophyll response to low-frequency NAO forcing, is more difficult to confirm in observational data sets. In fact basin-scale biogeochemical observations, long enough to resolve decadal variability, are extremely limited [e.g., Barton et al., 2003]. The confidence in the obtained results therefore lies in the capability of the model of reasonably simulating the physical mechanisms underlying the biogeochemical response. Indeed, the coupled model captures the observed strengthening of the subpolar gyre in decades of persistent NAO+ [Haekkinen and Rhines, 2004], the associated subpolar freshening and cooling [Bersch, 2002; Belkin, 2004], the reduced salinity inputs in the eastern subpolar gyre [Bersch, 2002], and the increase in sea ice in the Labrador Sea [Visbeck et al., 2003]. However, a caveat in the model simulation is its underestimation of NAO decadal variability which may reduce the amplitude of the ocean circulation response to decadal NAO wind forcing. As a result, also the associated anomalies of the physical and biogeochemical properties are likely underestimated in the model simulation.

[50] Despite these model caveats, this study uses for the first time a coupled climate model to investigate the biogeochemical response to the NAO on time scales from interannual to decadal. Whereas on interannual time scales local air-sea flux changes are most relevant, on decadal time scales slow advective adjustments to low-frequency NAO variability play an increasingly relevant role in determining the biogeochemical response to the NAO. This is a relevant piece of information, as the decadal time scales are also those on which the impacts of anthropogenic carbon emissions are likely to take place. This modeling framework thus opens the way to future research investigating the interaction between decadal natural variability and anthropogenic climate change in the North Atlantic Ocean under scenarios of increased anthropogenic carbon emissions.

[51] Acknowledgments. This study was funded by Centro EuroMediterraneo per i Cambiamenti Climatici (CMCC) and by the Italian FISR project VECTOR funded by the Ministry of University and Scientific Research. The authors thank the European Centre for Medium-Range Weather Forecasts (ECMWF) for making available ERA-40 wind stress data, NASA for providing SeaWiFS chlorophyll satellite products, the Bermuda Institute of Ocean Sciences for the in situ chlorophyll data collected at the Bermuda Atlantic Time series Study (BATS) station, the Hadley Centre for the sea surface temperature and sea ice cover data available on the Web site http://www.metoffice.gov.uk/hadobs, and the Climate Analysis Section of NCAR for providing the NAO Index data. Comments from three anonymous reviewers are gratefully acknowledged.

\section{References}

Alexander, M. A., and C. Deser (1995), A mechanism for the recurrence of wintertime midlatitude SST anomalies, J. Phys. Oceanogr., 25, 122-137, doi:10.1175/1520-0485(1995)025<0122:AMFTRO > 2.0.CO;2.

Barton, A. D., C. H. Green, B. C. Monger, and A. J. Pershing (2003), The continuous plankton recorder survey and the North Atlantic Oscillation: Interannual- to multidecadal-scale patterns of phytoplankton variability in the North Atlantic Ocean, Prog. Oceanogr., 58, 337-358, doi:10.1016/j.pocean.2003.08.012.

Bates, N. R. (2007), Interannual variability of the oceanic $\mathrm{CO}_{2}$ sink in the subtropical gyre of the North Atlantic Ocean over the last 2 decades, J. Geophys. Res., 112, C09013, doi:10.1029/2006JC003759. 
Belkin, I. M. (2004), Propagation of the "Great Salinity Anomaly" of the 1990s around the northern Atlantic, Geophys. Res. Lett., 31, L08306, doi:10.1029/2003GL019334.

Bellucci, A., S. Gualdi, E. Scoccimarro, and A. Navarra (2008), NAO-ocean circulation interactions in a coupled general circulation model, Clim. Dyn., 31, 759-777, doi:10.1007/s00382-008-0408-4.

Bersch, M. (2002), North Atlantic Oscillation-induced changes of the upper layer circulation in the northern North Atlantic Ocean, J. Geophys. Res., 107(C10), 3156, doi:10.1029/2001JC000901.

Bjerknes, J. (1964), Atlantic air-sea interactions, Adv. Geophys., 10, 1-82, doi:10.1016/S0065-2687(08)60005-9

Böning, C. W., M. Scheinert, J. Dengg, A. Biastoch, and A. Funk (2006), Decadal variability of subpolar gyre transport and its reverberation in the North Atlantic overturning, Geophys. Res. Lett., 33, L21S01, doi:10.1029/2006GL026906.

Cayan, D. R. (1992), Latent and sensible heat flux anomalies over the Northern Oceans driving the sea surface temperature, J. Phys. Oceanogr., 22(8), 859-881, doi:10.1175/1520-0485(1992)022<0859:LASHFA $>2.0$. $\mathrm{CO} ; 2$.

Conkright, M., H. Garcia, T. D. O’Brien, R. A. Locarnini, T. P. Boyer, C. Stephens, and J. Antonov (2002), World Ocean Atlas 2001, vol. 4 Nutrients, NOAA Atlas NESDIS, vol. 52, NOAA, Silver Spring, Md.

Corbière, A., N. Metzl, G. Reverdin, C. Brunet, and T. Takahashi (2007), Interannual and decadal variability of the oceanic carbon sink in the North Atlantic subpolar gyre, Tellus, Ser. B, 59(2), 168-179, doi:10.1111/j.1600-0889.2006.00232.x.

Curry, R. G., and M. S. McCartney (2001), Ocean gyre circulation changes associated with the North Atlantic Oscillation, J. Phys. Oceanogr., 31, 3374-3400, doi:10.1175/1520-0485(2001)031<3374:OGCCAW>2.0. $\mathrm{CO} ; 2$.

de Boyer Montégut, C., G. Madec, A. S. Fischer, A. Lazar, and D. Iudicone (2004), Mixed layer depth over the global ocean: An examination of profile data and a profile-based climatology, J. Geophys. Res., 109, C12003, doi:10.1029/2004JC002378.

Delworth, T. L., and M. E. Mann (2000), Observed and simulated multidecadal variability in the Northern Hemisphere, Clim. Dyn., 16(9), 661-676, doi:10.1007/s003820000075.

Denman, K. L., et al. (2007), Couplings between changes in the climate system and biogeochemistry, in Climate Change 2007: The Physical Science Basis. Contribution of Working Group I to the Fourth Assessment Report of the Intergovernmental Panel on Climate Change, edited by S. Solomon et al., pp. 501-587, Cambridge Univ. Press, Cambridge, U. K. Drinkwater, K. F., A. Belgrano, A. Borja, A. Conversi, M. Edwards, C. H Greene, G. Ottersen, A. J. Pershing, and H. Walker (2003), The response of marine ecosystems to climatic variability associated with the North Atlantic Oscillation, in The North Atlantic Oscillation: Climate Significance and Environmental Impact, Geophys. Monogr. Ser., vol. 134 edited by J. W. Hurrell et al., pp. 211-234, AGU, Washington, D. C.

Dutkiewicz, S., M. Follows, J. Marshall, and W. W. Gregg (2001), Interannual variability of phytoplankton abundances in the North Atlantic, Deep Sea Res., Part II, 48, 2323-2344, doi:10.1016/S0967-0645(00) 00178-8.

Eden, C., and T. Jung (2001), North Atlantic interdecadal variability: Oceanic response to the North Atlantic oscillation $(1865-1997)$, J. Clim. 14(5), 676-691, doi:10.1175/1520-0442(2001)014<0676:NAIVOR >2.0 $\mathrm{CO} ; 2$.

Esselborn, S., and C. Eden (2001), Sea surface height changes in the North Atlantic Ocean related to the North Atlantic Oscillation, Geophys. Res Lett., 28(18), 3473-3476, doi:10.1029/2001GL012863.

Flatau, M. K., L. Talley, and P. P. Niiler (2003), The North Atlantic Oscillation, surface current velocities, and SST changes in the subpolar North Atlantic, J. Clim., 16(14), 2355-2369, doi:10.1175/2787.1.

Fogli, P. G., E. Manzini, M. Vichi, A. Alessandri, L. Patara, S. Gualdi, E. Scoccimarro, S. Masina, and A. Navarra (2009), INGV-CMCC Carbon (ICC): A carbon cycle Earth system model, CMCC Res. Pap., 61, Euro-Mediter. Cent. for Clim. Change, Lecce, Italy.

Follows, M., and S. Dutkiewicz (2002), Meteorological modulation of the North Atlantic spring bloom, Deep Sea Res., Part II, 49, 321-344, doi:10.1016/S0967-0645(01)00105-9.

Follows, M., T. Ito, and S. Dutkiewicz (2006), On the solution of the carbonate chemistry system in ocean biogeochemistry models, Ocean Modell., 12(3-4), 290-301, doi:10.1016/j.ocemod.2005.05.004.

Fortuin, J. P. F., and H. Kelder (1998), An ozone climatology based on ozonesonde and satellite measurements, J. Geophys. Res., 103(D24), 31,709-31,734, doi:10.1029/1998JD200008.

Frankignoul, C., G. de Coëtlogon, T. M. Joyce, and S. Dong (2001), Gulf Stream variability and ocean-atmosphere interactions, J. Phys. Oceanogr., 31, 3516-3529, doi:10.1175/1520-0485(2002)031<3516: GSVAOA $>2.0 . \mathrm{CO} ; 2$.
Frankignoul, C., J. Deshayes, and R. Curry (2009), The role of salinity in the decadal variability of the North Atlantic meridional overturning circulation, Clim. Dyn., 33(6), 777-793, doi:10.1007/s00382-008-0523-2.

Garcia, H. E., R. A. Locarnini, T. P. Boyer, J. I. Antonov, M. M. Zweng, O. K. Baranova, and D. R. Johnson (2010), World Ocean Atlas 2009 vol. 4, Nutrients (Phosphate, Nitrate, Silicate), NOAA Atlas NESDIS, vol. 71, edited by S. Levitus, 398 pp., NOAA, Silver Spring, Md.

Geider, R. J., H. L. MacIntyre, and T. M. Kana (1997), Dynamic model of phytoplankton growth and acclimation: Responses of the balanced growth rate and the chlorophyll a: Carbon ratio to light, nutrient-limitation and temperature, Mar. Ecol. Prog. Ser., 148(1-3), 187-200, doi:10.3354/ meps 148187.

Gruber, N., C. D. Keeling, and N. R. Bates (2002), Interannual variability in the North Atlantic Ocean carbon sink, Science, 298, 2374-2378, doi:10.1126/science. 1077077

Haekkinen, S., and P. Rhines (2004), Decline of subpolar North Atlantic circulation during the 1990s, Science, 304, 555-559, doi:10.1126/ science. 1094917

Henson, S. A., I. Robinson, J. T. Allen, and J. J. Waniek (2006), Effect of meteorological conditions on interannual variability in timing and magnitude of the spring bloom in the Irminger Basin, North Atlantic, Deep Sea Res., Part I, 53, 1601-1615, doi:10.1016/j.dsr.2006.07.009.

Henson, S. A., J. P. Dunne, and J. L. Sarmiento (2009), Decadal variability in North Atlantic phytoplankton blooms, J. Geophys. Res., 114, C04013, doi:10.1029/2008JC005139.

Herbaut, C., and M. N. Houssais (2009), Response of the eastern North Atlantic subpolar gyre to the North Atlantic Oscillation, Geophys. Res. Lett., 36, L17607, doi:10.1029/2009GL039090.

Hurrell, J. W. (1995), Decadal trends in the North-Atlantic Oscillation: Regional temperatures and precipitation, Science, 269(5224), 676-679, doi:10.1126/science.269.5224.676.

Hurrell, J., Y. Kushnir, G. Ottersen, and M. Visbeck (2003), An overview of the North Atlantic Oscillation, in The North Atlantic Oscillation: Climate Significance and Environmental Impact, Geophys. Monogr. Ser, vol. 134, pp. 1-35, AGU, Washington, D. C.

Key, R. M., A. Kozyr, C. L. Sabine, K. Lee, R. Wanninkhof, J. L. Bullister, R. A. Feely, F. J. Millero, C. Mordy, and T.-H. Peng (2004), A global ocean carbon climatology: Results from Global Data Analysis Project (GLODAP), Global Biogeochem. Cycles, 18, GB4031, doi:10.1029/ $2004 \mathrm{~GB} 002247$.

Krahmann, G., M. Visbeck, and G. Reverdin (2001), Formation and propagation of temperature anomalies along the North Atlantic Current, J. Phys. Oceanogr., 31, 1287-1303, doi:10.1175/1520-0485(2001) $031<1287$ :FAPOTA $>2.0$. CO; 2 .

Le Quéré, C., J. C. Orr, P. Monfray, O. Aumont, and G. Madec (2000), Interannual variability of the oceanic sink of $\mathrm{CO}_{2}$ from 1979 to 1997 , Global Biogeochem. Cycles, 14, 1247-1265, doi:10.1029/ 1999GB900049.

Levitus, S., T. Boyer, M. Conkright, T. O’Brien, J. Antonov, C. Stephens, L. Stathoplos, D. Johnson, and R. Gelfeld (1998), World Ocean Database 1998, vol. 1, Introduction, NOAA Atlas NESDIS, vol. 18 , 346 pp., NOAA, Silver Spring, Md.

Lohmann, K., H. Drange, and M. Bentsen (2009), Response of the North Atlantic subpolar gyre to persistent North Atlantic oscillation like forcing, Clim. Dyn., 32(2-3), 273-285, doi:10.1007/s00382-008-0467-6.

Löptien, U., and C. Eden (2010), Multidecadal $\mathrm{CO}_{2}$ uptake variability of the North Atlantic, J. Geophys. Res., 115, D12113, doi:10.1029/ 2009JD012431.

Madec, G., and M. Imbard (1996), A global ocean mesh to overcome the North Pole singularity, Clim. Dyn., 12(6), 381-388, doi:10.1007/ BF00211684.

Madec, G., P. Delecluse, M. Imbard, and C. Levy (1998), OPA 8.1 Ocean General Circulation Model Reference Manual, Note du Pole de Model. 11, 91 pp., Inst. Pierre Simon Laplace, Paris.

Marshall, J., H. Johnson, and J. Goodman (2001), A study of the interaction of the North Atlantic Oscillation with ocean circulation, J. Clim., 14, 1399-1421, doi:10.1175/1520-0442(2001)014<1399:ASOTIO>2.0. $\mathrm{CO} ; 2$.

McClain, C. R. (2009), A decade of satellite ocean color observations, Annu. Rev. Mar. Sci., 1, 19-42, doi:10.1146/annurev.marine.010908. 163650 .

Mignot, J., and C. Frankignoul (2004), Interannual to interdecadal variability of sea surface salinity in the Atlantic and its link to the atmosphere in a coupled model, J. Geophys. Res., 109, C04005, doi:10.1029/ 2003JC002005

Olsen, A., R. G. J. Bellerby, T. Johannessen, A. M. Omar, and I. Skjelvan (2003), Interannual variability in the wintertime air-sea flux of carbon dioxide in the northern North Atlantic, 1981-2001, Deep Sea Res., Part I, 50, 1323-1338, doi:10.1016/S0967-0637(03)00144-4. 
Oschlies, A. (2001), NAO-induced long-term changes in nutrient supply to the surface waters of the North Atlantic, Geophys. Res. Lett., 28(9), 1751-1754, doi:10.1029/2000GL012328.

Palter, J. B., M. S. Lozier, and R. T. Barber (2005), The effect of advection on the nutrient reservoir in the North Atlantic subtropical gyre, Nature, 437(7059), 687-692, doi:10.1038/nature03969.

Randall, D. A., et al. (2007), Climate models and their evaluation, in Climate Change 2007: The Physical Science Basis. Contribution of Working Group I to the Fourth Assessment Report of the Intergovernmental Panel on Climate Change, edited by S. Solomon et al., pp. 591-662, Cambridge Univ. Press, Cambridge, U. K

Raynaud, S., O. Aumont, K. Rodgers, P. Yiou, and J. Orr (2006), Interannualto-decadal variability of North Atlantic air-sea $\mathrm{CO}_{2}$ fluxes, Ocean Sci., 2 , 43-60, doi:10.5194/os-2-43-2006.

Rayner, N. A., D. E. Parker, E. B. Horton, C. K. Folland, L. V. Alexander, D. P. Rowell, E. C. Kent, and A. Kaplan (2003), Global analyses of sea surface temperature, sea ice, and night marine air temperature since the late nineteenth century, J. Geophys. Res., 108(D14), 4407, doi:10.1029/2002JD002670.

Reverdin, G., P. P. Niiler, and H. Valdimarsson (2003), North Atlantic Ocean surface currents, J. Geophys. Res., 108(C1), 3002, doi:10.1029/ 2001JC001020.

Röckner, E., et al. (2003), The atmospheric general circulation model ECHAM5, part I: Model description, Rep. 349, Max Planck Inst. for Meteorol., Hamburg, Germany.

Sabine, C. L., et al. (2004), The oceanic sink for anthropogenic $\mathrm{CO}_{2}$, Science, 305, 367-371, doi:10.1126/science.1097403.

Schuster, U., and A. J. Watson (2007), A variable and decreasing sink for atmospheric $\mathrm{CO}_{2}$ in the North Atlantic, J. Geophys. Res., 112, C11006, doi:10.1029/2006JC003941.

Sutton, R., and M. Allen (1997), Decadal predictability of North Atlantic sea surface temperature and climate, Nature, 388, 563-567, doi: $10.1038 / 41523$

Sverdrup, H. U. (1953), On conditions for the vernal blooming of phytoplankton, J. Cons. Int. Explor. Mer, 18, 287-295.

Takahashi, T., J. Olafsson, J. Goddard, D. W. Chipman, and S. C. Sutherland (1993), Seasonal variation of $\mathrm{CO}_{2}$ and nutrients in the high-latitude surface oceans: A comparative study, Global Biogeochem. Cycles, 7, 843-878, doi:10.1029/93GB02263.

Tegen, I., and I. Fung (1994), Modeling of mineral dust in the atmosphere: Sources, transport, and optical thickness, J. Geophys. Res., 99, 22,89722,914, doi:10.1029/94JD01928.

Thomas, H., A. E. F. Prowe, I. D. Lima, S. C. Doney, R. Wanninkhof, R. J. Greatbatch, U. Schuster, and A. Corbière (2008), Changes in the North Atlantic Oscillation influence $\mathrm{CO}_{2}$ uptake in the North Atlantic over the past 2 decades, Global Biogeochem. Cycles, 22, GB4027, doi:10.1029/2007GB003167.

Timmermann, R., H. Goosse, G. Madec, T. Fichefet, C. Ethe, and V. Dulière (2005), On the representation of high latitude processes in the ORCA-LIM global coupled sea ice-ocean model, Ocean Modell., 8, 175-201, doi:10.1016/j.ocemod.2003.12.009.

United Nations Educational, Scientific, and Cultural Organization (1983), Algorithms for computation of fundamental properties of seawater, UNESCO Tech. Pap. Mar. Sci., 44, 53 pp., Paris.

Uppala, S. M., et al. (2005), The ERA-40 re-analysis, Q. J. R. Meteorol. Soc., 131, 2961-3012, doi:10.1256/qj.04.176.

Valcke, S., A. Caubel, R. Vogelsang, and D. Declat (2004), Oasis3 ocean atmosphere sea ice soil user's guide, Tech. Rep. TR/CMGC/04/68, Eur. Cent. for Res. and Adv. Training in Sci. Comput., Toulouse, France.

Vichi, M., and S. Masina (2009), Skill assessment of the PELAGOS global ocean biogeochemistry model over the period 1980-2000, Biogeosciences, 6, 2333-2353, doi:10.5194/bg-6-2333-2009.

Vichi, M., S. Masina, and N. Pinardi (2007a), A generalized model of pelagic biogeochemistry for the global ocean ecosystem. Part I: Theory, J. Mar. Syst., 64, 1-4, 89-109.

Vichi, M., S. Masina, and A. Navarra (2007b), A generalized model of pelagic biogeochemistry for the global ocean ecosystem. Part II: Numerical simulations, J. Mar. Syst., 64(1-4), 110-134, doi:10.1016/j. jmarsys.2006.03.014.

Visbeck, M., H. Cullen, G. Krahmann, and N. Naik (1998), An ocean model's response to North Atlantic Oscillation-like wind forcing, Geophys. Res. Lett., 25(24), 4521-4524, doi:10.1029/1998GL900162.

Visbeck, M., E. P. Chassignet, R. G. Curry, T. L. Delworth, R. R. Dickson, and G. Krahmann (2003), The ocean's response to North Atlantic oscillation variability, in The North Atlantic Oscillation: Climatic Significance and Environmental Impact, Geophys. Monogr. Ser., vol. 134, edited by J. W. Hurrell et al., pp. 113-145, AGU, Washington, D. C.

Walker, G. T., and E. W. Bliss (1932), World weather V, Mem. $R$. Meteorol. Soc., 4, 53-84.

Wanninkhof, R. (1992), Relationship between wind speed and gas exchange over the ocean, J. Geophys. Res., 97, 7373-7382, doi:10.1029/92JC00188

Watson, A. J., et al. (2009), Tracking the variable North Atlantic sink for atmospheric $\mathrm{CO}_{2}$, Science, 326(5958), 1391-1393, doi:10.1126/ science.1177394.

Zeebe, R. E., and D. A. Wolf-Gladrow (2001), $\mathrm{CO}_{2}$ in Seawater: Equilibrium, Kinetics, Isotopes, Oceanogr. Ser., vol. 65, 346 pp., Elsevier, Amsterdam.

G. Krahmann, L. Patara, and M. Visbeck, Leibniz Institute of Marine Sciences at University of Kiel (IFM-GEOMAR), Düsternbrooker Weg 20, D-24105 Kiel, Germany. (gkrahmann@ifm-geomar.de; lpatara@ ifm-geomar.de; mvisbeck@ifm-geomar.de)

S. Masina and M. Vichi, Centro Euro-Mediterraneo per i Cambiamenti Climatici, Viale Aldo Moro 44, I-40127 Bologna, Italy. (simona. masina@bo.ingv.it; marcello.vichi@bo.ingv.it) 